\title{
Optimization of mechanical properties of cellular lightweight concrete with alkali treated banana fiber
}

\author{
Mohammed Hassan Nensok (D)1, Md Azree Othuman Mydin*iD2, Hanizam Awang (D) 3 \\ 1 School of Housing, Building and Planning, Universiti Sains Malaysia, Penang (Malaysia), nensok@ stu- \\ dent.usm.my; azree@usm.my; hanizam@usm.my \\ *Correspondence: azree@usm.my
}

Received: 28.01.2021; Accepted: 21.12.2021; Published: 31.12.2021

Citation: Nensok, M., Mydin, A., Awang, H. (2021). Optimization of mechanical properties of cellular lightweight concrete with alkali treated banana fiber. Revista de la Construcción. Journal of Construction, 20(3), 491-511. https://doi.org/10.7764/RDLC.20.3.491.

\begin{abstract}
Recent advancements in construction materials development have involved the utilization of plant-based natural fibers such as kenaf, sisal, coir and banana to replace conventional fibers such as carbon, steel, polypropylene and aramid. However, the main issue with using these fibers is the alkaline cement matrix's durability and compatibility due to high water absorption. Hence, this research focuses on the use of alkali treatment of banana fibers to enhance the mechanical properties of cellular lightweight concrete (CLC). Banana fibers were subjected to 2\%, 4\%, 6\%, $8 \%$, and $10 \% \mathrm{NaOH}$ treatment before being included in $1200 \mathrm{~kg} / \mathrm{m} 3$ density CLC. Plain CLC and untreated fiber composites $(0 \% \mathrm{NaOH}$ treatment) were used as the control. Results from the study indicate that compared to the untreated fibre composites and plain control CLC at 28 days, compressive, flexural and splitting tensile strengths increased simultaneously with $6 \% \mathrm{NaOH}$ fibre treatment to peaks of $40.6 \%$ and $59.8 \%, 63.8 \%$ and $117.4 \%$, and $77.4 \%$ and $157.8 \%$ respectively. The $6 \% \mathrm{NaOH}$ treatment of BF tremendously improved the mechanical characteristics of single fibers and BFRCLC composites. It is therefore concluded that $6 \% \mathrm{NaOH}$ treatment of banana fibre was the optimum percentage alkali treatment for use in CLC.
\end{abstract}

Keywords: foamed concrete; banana fibre; mechanical properties; compressive strength; flexural strength.

\section{Introduction}

Cellular lightweight concrete (CLC), otherwise known as foamed concrete, is a cementitious lightweight material containing numerous evenly distributed air bubbles in the matrix, produced by mixing water with the cement, filler (sand) and at least $20 \%$ air bubbles from a foaming agent (Risdanareni, Sulton, \& Nastiti, 2016). The air bubbles produced in CLC usually serve as the coarse aggregate in the matrix since there is no coarse aggregate in CLC (Aini, Sari, Rahim, \& Sani, 2017). This makes the concrete cheaper and greener since mineral gravel, which is very heavy and expensive, is not required. CLC has excellent thermal and acoustic insulating properties as a partition or masonry material in building walls, making it an energy-efficient construction material (Othuman Mydin, Musa, \& Abdul Ghani, 2018). CLC is an effective fire-resistant material (Othuman Mydin, Zamzani, \& Abdul Ghani, 2020). It has been reported by (Othuman et al., 2020) that at elevated temperatures, the incorporation of Cocos nucifera Linn into FC improves the mechanical and ductility performance of FRFC.

Another interesting benefit of CLC is its production flexibility at variable densities and applications (Raj, Sathyan, \& Mini, 2019). It can be produced at a very low-density range from $250 \mathrm{~kg} / \mathrm{m}^{3}$ to $600 \mathrm{~kg} / \mathrm{m}^{3}$ (non-structural), mostly used as an insulating material and filler (Othuman Mydin, Zamzani, \& Abdul Ghani, 2018; Nensok, Othuman Mydin, \& Awang, 2021). 
Despite all these benefits associated with CLC, its greatest limitation is its weakness in tension (Mohamad et al., 2018). The airspace found in its matrix has very low compressive and flexural strength than normal concrete and mortar. Its compressive strength ranges from 1-25 MPa, depending on the target dry density (Harith, 2018). The flexural strength of CLC is normally ten times lower than its compressive strength, and therefore there is a high tendency for flexural cracking to occur. Several researchers have reported that the incorporation of natural fibres into lightweight concrete materials helps to improve ductility and mechanical characteristics of composites due it lightweight and embodied energy (Castillo-Lara et al., 2020; Kavitha, Venkatesan, Avudaiappan, \& Saavedra Flores, 2020; Madhwani, Sathyan, \& Mini, 2020; Yavuz Bayraktar, Kaplan, Gencel, Benli, \& Sutcu, 2021). Hence, the choice of natural fibre to improve the mechanical performance of CLC is justified.

Vo and Navard (2016) identified two major approaches to modifying the durability problem of plant-based natural fibres: material modifications and matrix modifications. The former modifications include coating and impregnation, chemical treatment, physical treatment and mixed treatments. Meanwhile, the latter include simply accelerated carbonation and the addition of pozzolanas such as pulverised fuel ash (PFA), rice husk ash (RHA) and silica fume (SF). Chemical treatment of plantbased natural fibres is varied and includes, among others, peroxide treatment, saline emulsion treatment, and alkali treatment. Among all these chemical treatments, alkali treatment of plant-based fibre is the easiest, cheapest and most common. Hence, for these reasons, from these surface treatment methods of fibres, this study intends to adopt an alkaline treatment of banana fibre for use in the CLC matrix. Hence, to overcome all the deficiencies identified above, this study intends to optimise the alkaline treatment of banana fibre reinforced cellular lightweight concrete (BFRCLC).

Awang \& Ahmad (2014) studied synthetic and natural fibres consisting of AR glass, polypropylene, steel, kenaf and oil palm fibre (OPF) in a CLC matrix. Durability tests such as water absorption and shrinkage were conducted on each CLC composite inculcating these fibres, and the results were compared. Kenaf and OPF fibres were treated with a $0.1 \mathrm{~mole} \mathrm{NaOH}$ solution before being added to CLC. Results indicated that despite the treatment, Kenaf and OPF absorb more water than synthetic fibres. In general, the addition of fibre improves the drying property of the composites. A research effort conducted by Awang, Ahmad, and Al-Mulali (2015), compared the influence of kenaf fibre and polypropylene fibre in CLC. Kenaf fibre was subjected to $0.1 \mathrm{Mole} \mathrm{NaOH}$ treatment for 24 hours before being used in the FC composites. Results indicated an increase in compressive, splitting tensile and flexural strength of both Kenaf and polypropylene fibres. In these two studies, an identical type of treatment was conducted without optimisation of the $\mathrm{NaOH}$ solutions.

Recent research by Mahzabin, Hock, Hossain and Kang (2018) reported using kenaf fibre subjected to a 12-hour treatment in a solution of $6 \% \mathrm{NaOH}$. Results indicated that alkaline treatment cleans the surface of kenaf fibre, thereby improving the surface adhesion. Recently, Raj, Sathyan, Madhavan and Raj (2020) undertook an investigation comparing the performance of a hybrid fibre and a mono-type fibre reinforced with both synthetic and natural fibre. The synthetic fibre was polyvinyl alcohol, while the natural fibre was coir fibre. The coir fibre was treated with $\mathrm{NaOH}$ solution. Results from the study showed a significant improvement in the durability properties of treated hybrid fibre compared to mono-type fibre. In another study undertaken by Musa, Othuman Mydin, and Abdul Ghani (2019) on oil palm empty fruit bunch (EFB), it was reported that $6 \% \mathrm{NaOH}$ treatment of EFB fibre resulted in the optimum mechanical property of the NFRFC. A similar study conducted using caustic soda solutions in the treatment of cocos Nucifera linn. It was reported that a $4.5 \%$ caustic soda concentration is optimum for improved mechanical performance (Mohd Zamzani, Othuman Mydin, \& Abdul Ghani, 2019).

Banana fibre has similar mechanical properties to some synthetic fibres such as glass and polypropylene (refer Table 1). Banana fibres' single fibre strand mechanical properties were recorded to be between 355-384 MPa tensile strength, 20-51 GPa modulus of elasticity, and 45\%-53\% elongation at break (Pacheco-Torgal \& Jalali, 2011). A much higher value of 54$740 \mathrm{MPa}$ for tensile strength was reported by Subagyo and Chafidz (2018), which is higher than that of AR glass and polypropylene fibre. Hence, fibres from the banana trunk could serve as green sustainable construction materials in the construction industry in synthetic fibres such as glass, polypropylene and carbon. The use of banana fibre in CLC could also help to improve the thermal, insulating and acoustic properties of banana fibre reinforced composites. Banana fibre is a low-cost building material whose production emits little or no $\mathrm{CO}_{2}$ compared to synthetic fibre but rather releases $\mathrm{O}_{2}$ to the atmosphere. Furthermore, CLC is very brittle and fragile with high shrinkage. Therefore, introducing banana fibre into its matrix could improve its properties, such as fracture toughness (Mahzabin et al., 2018). 
Despite the interesting improvement of mechanical properties and numerous applications of concrete composites by adding banana trunk fibre, to the best of the researchers' knowledge, no study has been conducted or reported for alkali-treated BFRCLC. Previous studies on alkali treatment optimisation of coir and oil palm empty fruit fibres focus only on fibres' mechanical and durability properties in composites of CLC(Musa et al., 2019; Mydin, Zamzani, et al., 2018). Attempting to bridge these gaps, this research aimed to investigate the mechanical properties of alkali-treated and untreated BFRCLC. This aim incorporated the following objectives: to demonstrate the sourcing, processing and alkali treatment of locally available banana fibre; to determine the influence of alkali treatment of the banana fibres on the morphology, microstructure and single fibre mechanical properties; to assess the impact of the alkali treatment on the mechanical properties of the BFRFC composites and to show how the impact of the treatment on single fibres affected the final mechanical properties of the composites; and finally to optimise the percentage concentration of alkali treatment of banana fibre in CLC composites.

Table 1. Comparison of physical and mechanical properties of selected natural and synthetic fibres.

\begin{tabular}{lllllll}
\hline & \multicolumn{7}{c}{ Names and properties of fibers } \\
\hline Properties & Banana & Banana & Coir & Kenaf & AR glass & Polypropylene \\
\hline Water absorption (\%) & 40.7 & - & - & 17 & - & - \\
Length $(\mathrm{mm})$ & - & $30-50$ & $17-19$ & 2.4 & 12 & 12 \\
Diameter $(\mu \mathrm{m})$ & - & $80-250$ & $125-1310$ & 19.8 & 50 & 25 \\
Aspect ratio & - & 150 & - & 121 & - & - \\
Tensile strength (MPa) & $355-384$ & $54-740$ & 154 & $223-930$ & $330-414$ & $240-550$ \\
Young modulus (GPa) & $20-51$ & $7.7-20$ & 5.37 & $14.5-53$ & - & $1.5-4.5$ \\
Elongation at break & $45-53$ & 10.35 & 28.2 & $1.5-2.7$ & - & $50-80$ \\
\hline References & (Pacheco-Torgal & (Subagyo, & (Othuman et & (Yan, Kasal, & (Sujatha \& & (Pakravan, \\
& \& Jalali, 2011) & Chafidz, & al., 2020) & \& Huang, & Selsia Devi, & Jamshidi, \& \\
& & 2018) & 2016) & 2018) & Latifi, 2016) \\
\hline
\end{tabular}

\section{Materials, mix proportions and experimental setup}

\subsection{Materials}

The river sand was obtained and prepared following BS EN 12620 (BSI, 2013). The sand was first dried in the laboratory and then sieved using a $1.18 \mathrm{~mm}$ sieve to obtain a finer sand material for foamed concrete production. Sieve analysis of the fine sand was conducted to ascertain the gradation and is given in Table 2. The sand could be considered fine sand, finer than 1.18 sieve size from the sieve analysis result. Other properties of the fine sand are given in Table 3 . The cement used was Ordinary Portland Cement (OPC) purchased from YTL Cement Bhd, Malaysia. Table 4 shows the chemical composition of the cement. The cement conforms to BS EN 197-1: (2011) specifications for Portland cement. Clean potable tap water was used for the mix. A protein-based foaming agent produced in Malaysia was used as a surfactant. The banana (Musa Musaceae) trunk fibre used for this study was harvested directly from a banana farm in Titi-Teras, a small suburb of Balik Pulau, Penang, as shown in Fig 2(a).

Table 2. Sieve analysis of fine sand.

\begin{tabular}{ccll}
\hline Sieve sizes & Percentage retained $(\%)$ & Cumulative percentage retained $(\%)$ & Percentage passing $(\%)$ \\
\hline 2.36 & 0.00 & 0.00 & 100.00 \\
1.18 & 0.07 & 0.07 & 99.93 \\
0.600 & 37.03 & 37.1 & 62.90 \\
0.300 & 29.83 & 66.93 & 33.07 \\
0.150 & 22.89 & 89.82 & 10.18 \\
0.75 & 7.37 & 97.19 & 2.81 \\
Pan & 2.81 & 100 & 0.00 \\
\hline
\end{tabular}


Table 3. Physical properties of fine sand.

\begin{tabular}{lll}
\hline S/No. & Properties & Values \\
\hline 1 & Specific gravity & 2.57 \\
2 & Bulk density loose $\left(\mathrm{kg} / \mathrm{m}^{3}\right)$ & 1429.55 \\
3 & Bulk density compacted $\left(\mathrm{kg} / \mathrm{m}^{3}\right)$ & 1548.86 \\
4 & Fineness modulus $(\%)$ & 1.93 \\
5 & Water absorption $(\%)$ & 0.78 \\
\hline
\end{tabular}

Table 4. Chemical composition of OPC.

\begin{tabular}{lll}
\hline S/No. & Cement oxides & Oxide composition $(\%)$ \\
\hline 1 & Silica oxide $\left(\mathrm{SiO}_{2}\right)$ & 16.84 \\
2 & Aluminium oxide $\left(\mathrm{Al}_{2} \mathrm{O}_{3}\right)$ & 5.84 \\
3 & Calcium oxide $(\mathrm{CaO})$ & 65.95 \\
4 & Ferric oxide $\left(\mathrm{Fe}_{2} \mathrm{O}_{3}\right)$ & 2.64 \\
5 & Sulphur oxide $\left(\mathrm{SO}_{3}\right)$ & 2.76 \\
6 & Magnesium $\mathrm{Oxide}(\mathrm{MgO})$ & 1.49 \\
7 & Phosphorus $\left(\mathrm{P}_{2} \mathrm{O}\right)$ & 0.08 \\
8 & Potassium oxide $\left(\mathrm{K}_{2} \mathrm{O}\right)$ & 0.87 \\
9 & Loss of ignition & - \\
\hline
\end{tabular}

\subsection{Fibre processing and treatment}

\subsubsection{Banana fibre processing and treatment with $\mathrm{NaOH}$}

The fibre was cut into much smaller pieces with an average length of 100mm, as shown in Fig. 1(b). The cut pieces of the trunk were then passed through the mechanical refiner, as shown in Fig. 1(c). The final product was a mechanically refined banana trunk fibre with an average length of 50mm. Some studies (Mostafa \& Uddin, 2016) have shown that longer banana fibre improves better flexural, compressive and ductility of bricks or mortar than shorter fibres. Hence, the 50mm fibre length choice is in line with such studies (Kavitha et al., 2020; Mostafa \& Uddin, 2016). The fibre was collected and drained in the spinner for about 15 minutes before it was left dry for 72 hours in the laboratory with a room temperature of about $25^{\circ}-37^{\circ} \mathrm{C}$.

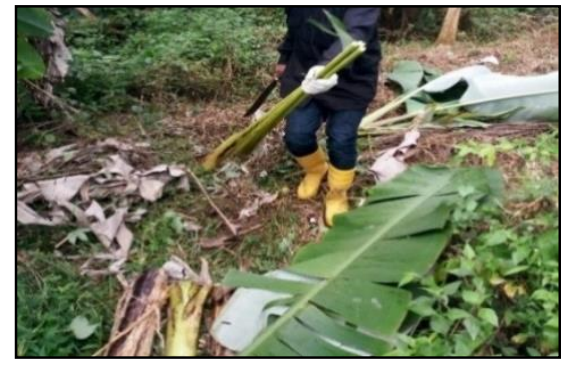

(a)

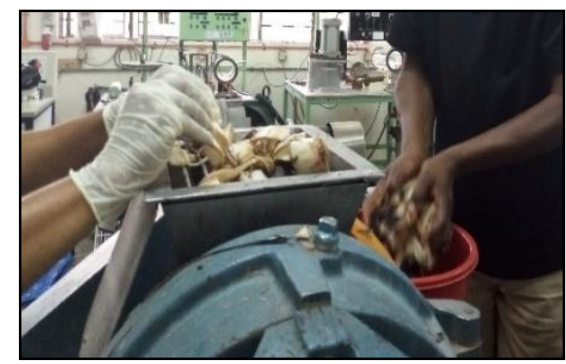

(c)

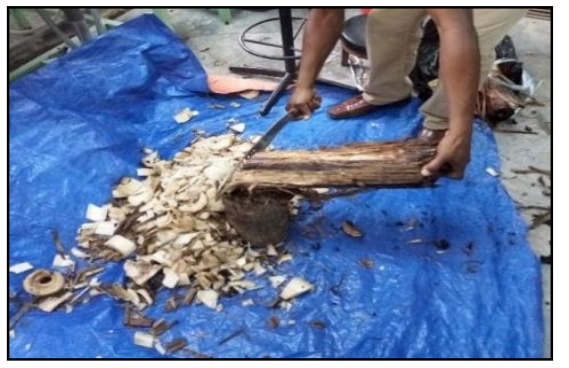

(b)

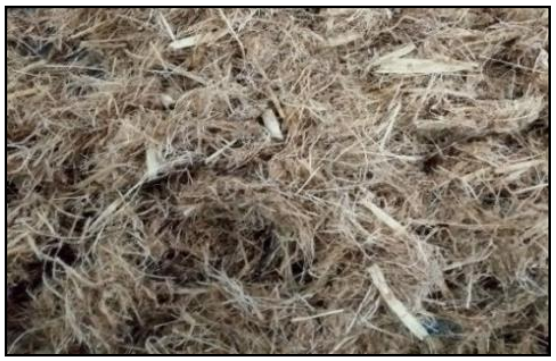

(d)

Figure 1. (a) Banana trunk cut from the farm; (b) banana trunk cut into smaller pieces for mechanical processing; (c) mechanical refining of banana trunk; (d) mechanically processed raw banana fibre (untreated). 
The dried fibre was the raw banana fibre used in this study, as shown in Fig. 1(d). The raw banana fibre was then measured and prepared for the $\mathrm{NaOH}$ treatment. The percentage of fibre content used in this study was $0.4 \%$ of the total volume fraction, in line with the work carried out by Awang et al. (2015). Amran et al. (2020) recommended that low fibre content is prescribed for Foamed concrete (FC) to achieve optimal properties. Raj et al. (2020) opined that the volumetric fraction of fibres in FRFC is between $0.2-0.45 \%$. Hence, in line with the above, this study adopted a constant volume fraction of $0.4 \%$ to determine the influence of alkali treatment of the banana fibre in the FC matrix. Sodium hydroxide pellets grade AR were used in the form of white amorphous tablets.

Tap water was used to prepare the solution of $\mathrm{NaOH}$ with different percentage concentrations. The $\mathrm{NaOH}$ solution concentrations were prepared using weight per volume percentage (w/v \%). The percentage concentrations were $2 \%, 4 \%, 6 \%$, $8 \%$, and $10 \%$. For a $2 \%$ concentration of $\mathrm{NaOH}, 5$ litres of water were measured, and 100 grams of the $\mathrm{NaOH}$ pellets were dissolved in the 5 litres $(5000 \mathrm{ml})$ of water and mixed thoroughly with a long stick (mixer) before the banana fibres were introduced. The banana fibre was fully immersed in the solution for proper treatment.

Similarly, for $4 \%, 6 \%, 8 \%$, and $10 \% \mathrm{NaOH}$ concentrations, $200 \mathrm{~g}, 300 \mathrm{~g}, 400 \mathrm{~g}, 500 \mathrm{~g}$ respectively of the pellet's tablets were dissolved in 5 litres $(5000 \mathrm{ml})$ of water obtain the various percentage concentrations of the mix. After 24 hours at laboratory ambient temperature $\left(25^{\circ} \mathrm{C}\right)$ treatments in various concentrations of $\mathrm{NaOH}$ solution, the fibres were removed from the solutions and washed several times manually and tested for alkalinity using a digital $\mathrm{pH}$ tester before being dried in the laboratory at room temperature for another 76 hours. The $\mathrm{pH}$ tester value recorded was seven before the washing stopped. A weak acetic acid or hydrochloric acid could be used to neutralise the alkali solution of $\mathrm{NaOH}$ while the treated fibre was being washed.

Figure 2(a-f) shows the physical and colour changes at the various percentages of $\mathrm{NaOH}$ treatment of banana fibres. The change in colour was striking and a good testimony of the physical changes that occur due to the percentage $\mathrm{NaOH}$ treatment of these fibres. The colours changed from the dirty brownish-yellow of the untreated fibre to the golden-brown $2 \%$ treated fibre. Other changes were the golden brownish-yellow of the $4 \%$ treated fibre to the golden yellow $6 \%$ treated fibre, followed by the slightly faded golden yellow $8 \%$ treated fibre, up to the fully faded golden yellow $10 \%$ treated fibre. Apart from the colour change reported, there was also a change in the chemical composition of the treated and untreated banana fibre. After the single fibre test optimisation, a test was undertaken using the deconstruction method to determine the chemical composition of the treated and the untreated banana fibre. The result of this test is shown in table 3 . The result indicates that cellulose content increases with increased alkali concentration treatment, but hemicellulose, lignin, and ash content decreases.

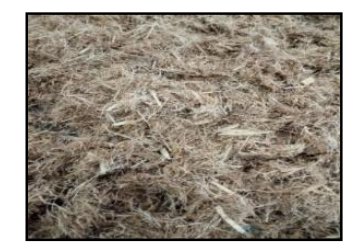

(a)

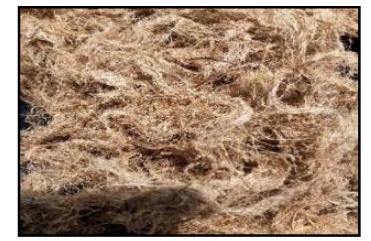

(d)

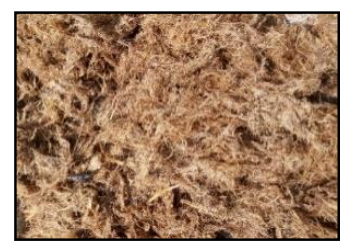

(b)

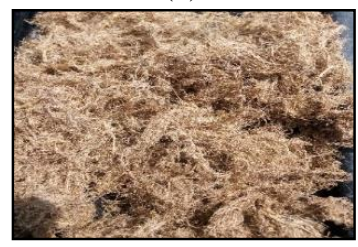

(e)

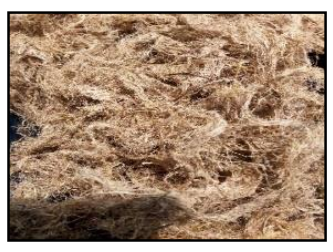

(c)

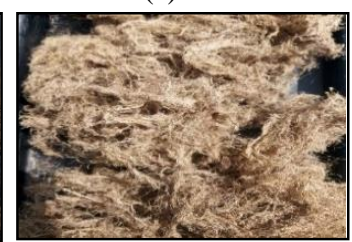

(f)

Figure 2. Physical and colour changes evident in the various percentages of $\mathrm{NaOH}$ treatment of banana fibres (a) untreated banana fibre; (b) $2 \% \mathrm{NaOH}$ treated fibre; (c) $4 \% \mathrm{NaOH}$ treated fibre; (d) $6 \% \mathrm{NaOH}$ treated fibre; $8 \% \mathrm{NaOH}$ treated fibre; (f) $10 \% \mathrm{NaOH}$ treated fibre. 
Table 5. Chemical composition of treated and untreated banana fibre.

\begin{tabular}{llccccc}
\hline Constituents & Untreated BF & $\begin{array}{c}2 \% \\
\mathrm{NaOH}\end{array}$ & $\begin{array}{c}4 \% \\
\mathrm{NaOH} \\
\text { treated BF }\end{array}$ & $\begin{array}{c}\text { Treated BF } \\
\text { NaOH } \\
\text { treated BF }\end{array}$ & $\begin{array}{l}8 \% \\
\mathrm{NaOH} \\
\text { treated BF }\end{array}$ & $\begin{array}{c}10 \% \\
\mathrm{NaOH} \\
\text { treated B }\end{array}$ \\
\hline Cellulose & 53.20 & 57.11 & 59.85 & 68.56 & 63.56 & 61.90 \\
Hemicellulose & 28.60 & 12.12 & 9.74 & 6.16 & - & - \\
Lignin & 15.10 & 13.92 & 12.47 & 10.05 & 9.23 & 6.35 \\
Wax & 0.98 & 0.86 & 0.75 & 0.52 & 0.39 & 0.27 \\
Moisture & 11.60 & 9.65 & 7.11 & 6.35 & 4.89 & 3.17 \\
Ash content & 1.02 & 0.87 & 0.66 & 0.42 & - & - \\
\hline
\end{tabular}

\subsubsection{Test for the mechanical properties of a single banana fibre strand}

After the treatments of the fibres at various percentage concentrations of alkali solution, single strand fibre samples were selected from each of the treated fibres $(2 \%, 4 \%, 6 \%, 8 \%$, and $10 \%)$ and untreated fibres ( $0 \%$-control sample). Fifteen of each single strand fibre with an average length of $50 \mathrm{~mm}$ were selected from each of the six different samples and subjected to single fibre mechanical testing, including tensile strength, modulus of elasticity and elongation at break. Before the testing was conducted, each fibre strand was measured for physical properties such as fibre length $(\mathrm{mm})$ and diameter $(\mathrm{mm})$. The actual fibre length was $50 \mathrm{~mm} \pm 5 \mathrm{~mm}$, randomly selected from each treated and untreated sample. The fibres' cross-sectional diameters were then individually measured. The test was conducted based on ASTM C 1557-14 (2014). The effective length of the single fibres used for the test was $30 \mathrm{~mm}$, while $10 \mathrm{~mm}$ at both ends was utilised as gauge length or support gauge length. Figure 3 shows the set-up for a single fibre mechanical property test.

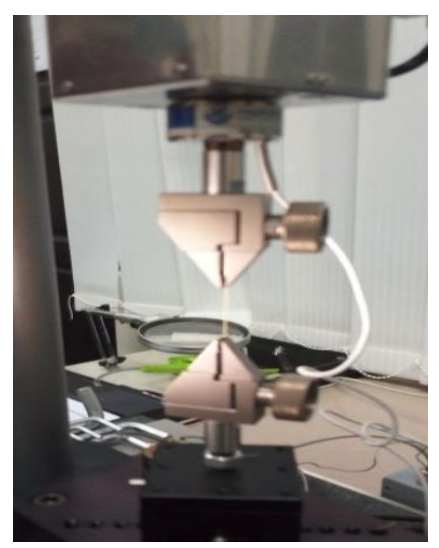

Figure 3. Set up for single fibre mechanical property test.

\subsection{Mix proportion}

A Portafoam PM1 foam generating machine was used to produce a stable foam with foam density in the range of 65-70 g/l. A pre-foaming mixing method was adopted to produce CLC. The protein foaming agent was first diluted in a water solution using a mix ratio of 1:30 (Foaming agent: water). The CLC mix ratio was 1:1.5:0.45 (cement: sand: water), adding fibre at $0.4 \%$ of the total volume fraction of the mix. CLC with a dry density of $1200 \mathrm{~kg} / \mathrm{m}^{3}$ was targeted. Table 6 shows the mixed proportions of all the materials used in the preparation of the samples. A total of seven mix batches were conducted, as shown in Table 1. Two control mix batches were produced. The first control mix was of plain CLC coded as P-Control, with no fibre addition, while the second control mix was with untreated fibre addition coded as BFU-Control. The other five batches for alkali-treated banana fibres at $2 \%, 4 \%, 6 \%, 8 \%$ and $10 \%$ were coded as $\mathrm{BF} 2 \% \mathrm{NaOH}, \mathrm{BF} 4 \% \mathrm{NaOH}, \mathrm{BF} 6 \% \mathrm{NaOH}$, $\mathrm{BF} 8 \% \mathrm{NaOH}$ and $\mathrm{BF} 10 \% \mathrm{NaOH}$ in that order. 
Table 6. Mix proportioning of materials in production of $1200 \mathrm{~kg} / \mathrm{m}^{3}$ density BFRCLC.

\begin{tabular}{|c|c|c|c|c|c|c|c|}
\hline Batch & Description & Ref. code & $\begin{array}{l}\text { Cement } \\
(\mathrm{kg})\end{array}$ & $\begin{array}{l}\text { Sand } \\
(\mathrm{kg})\end{array}$ & $\begin{array}{l}\text { Water } \\
(\mathrm{kg})\end{array}$ & $\begin{array}{l}\text { Fibre } \\
(\mathrm{kg})\end{array}$ & $\begin{array}{l}\text { Foam } \\
\text { (litre) }\end{array}$ \\
\hline 1 & Plain CLC-control & P-control & 22.35 & 33.52 & 10.06 & 0.000 & 19 \\
\hline 2 & Untreated fibre-control & BFU-control & 22.35 & 33.52 & 10.06 & 0.264 & 19 \\
\hline 3 & $2 \% \mathrm{NaOH}-$ treated & $\mathrm{BF} 2 \% \mathrm{NaOH}$ & 22.35 & 33.52 & 10.06 & 0.264 & 19 \\
\hline 4 & $4 \% \mathrm{NaOH}-$ treated & $\mathrm{BF} 4 \% \mathrm{NaOH}$ & 22.35 & 33.52 & 10.06 & 0.264 & 19 \\
\hline 5 & $6 \% \mathrm{NaOH}-$ treated & $\mathrm{BF} 6 \% \mathrm{NaOH}$ & 22.35 & 33.52 & 10.06 & 0.264 & 19 \\
\hline 6 & $8 \% \mathrm{NaOH}$ - treated & $\mathrm{BF} 8 \% \mathrm{NaOH}$ & 22.35 & 33.52 & 10.06 & 0.264 & 19 \\
\hline 7 & $10 \% \mathrm{NaOH}-$ treated & $\mathrm{BF} 10 \% \mathrm{NaOH}$ & 22.35 & 33.52 & 10.06 & 0.264 & 19 \\
\hline
\end{tabular}

\subsection{Experimental set-up}

\subsubsection{Compressive strength test}

The test for compressive strength of banana fibre reinforced CLC was conducted using a steel mould of size $100 \mathrm{x} 100 \mathrm{x}$ $100 \mathrm{~mm}$. The test was conducted based on curing periods of 7, 28, and 56 days. The compressive strength of CLC was determined using BS EN 12390- Part 3 (2019). This test was conducted with the aid of a GoTech GT-7001-BS300 universal testing machine with a capacity of $3000 \mathrm{kN}$. Three CLC specimens were produced for each testing period, and the average compressive strength for the three was recorded as the compressive strength at each curing period. The test set-up is shown in Figure 4 (a).

\subsubsection{Flexural strength test}

A three-point bending test, as display in Figure 4 (b), was conducted to determine the flexural strength of BFRCLC. The test was conducted using three samples of a specimen size $(40 \times 40 \times 160) \mathrm{mm}$ beam at each curing period of 7, 28 and 56 days. The effective span from supports of the beam was measured as $120 \mathrm{~mm}$. The average of each of the three specimens was used as flexural strength at each hydration period. This test was conducted following ASTM C348 (2020). The test was conducted in the laboratory using a GoTech GT-7001-BS300 universal testing machine.

\subsubsection{Splitting tensile strength test}

The splitting tensile strength of BFRCLC was determined using a cylindrical mould of size $100 \mathrm{~mm}$ diameter x $200 \mathrm{~mm}$ depth. Three samples of the specimen were produced for each of the curing periods of 7, 28 and 56 days. The average of the three specimens was recorded as the splitting tensile strength of the CLC. The test specimen was prepared and tested under ASTM C496/ C496M-17 (2017). The test was also conducted in HBP testing units with a GoTech GT-7001-BS300 universal testing machine. Figure 4 (c) display the set-up for the splitting tensile strength test.

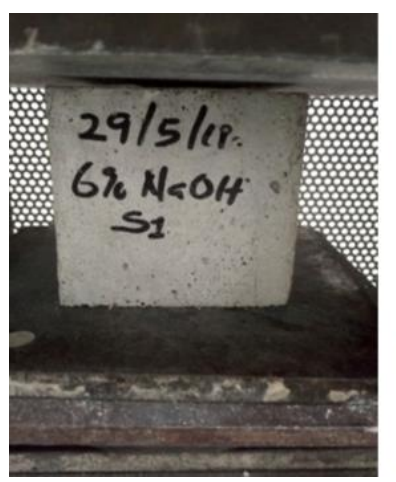

(a)

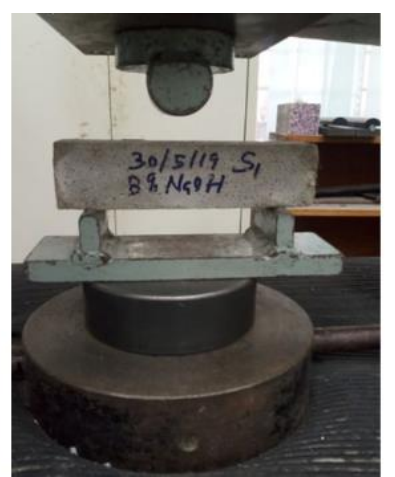

(b)

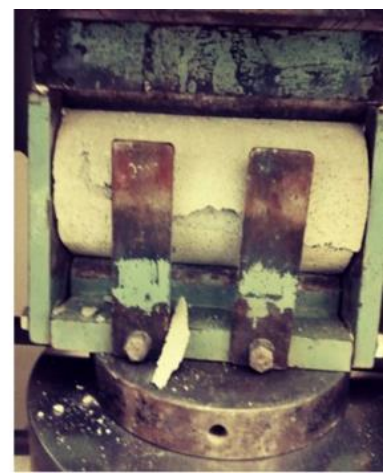

(c)

Figure 4. Test set up for mechanical properties of BFRCLC (a) compression test; (b) flexural test; (c) tensile test. 


\subsubsection{Ultra-sonic pulse velocity (UPV)}

This test was conducted to determine the non-destructive velocity of the fibre reinforced CLC composites produced in the study. The test was conducted on a concrete cube produced for a compressive strength test. The non-destructive test was conducted before the specimen was tested for compressive strength test in all cases at each curing period. In this study, measurement of pulse velocity was conducted by placing the two transducers, i.e., the receiver transducer (R) and the transmitter transducer (T), on opposites faces (direct transmission). The test was conducted according to (BS EN 12504-4, 2004).

\subsubsection{Scanning electron microscopy (SEM)}

Samples of treated and untreated fibres and BFRCLC composites were subjected to scanning electron microscopy (SEM) to ascertain their microstructural properties at various percentage concentrations before and after $\mathrm{NaOH}$ treatment. Samples from the treated and untreated fibres and BFRCLC composites were first placed in an SEM specimen stub. Then the specimens were placed inside a coating machine to be sputter coated with gold layers before they were tested.

\subsubsection{Chemical deconstruction and FTIR spectroscopy test}

The chemical deconstruction technique was conducted on raw banana fibre and all the treated banana fibre samples. The technique was undertaken following the method described by (Sango et al., 2018) as adopted from (Neto et al., 1996). The methods involve five major steps. The first step is the determination of lipo-soluble extractives (LSE). This was followed by the determination of water-soluble extractive (WSE) at the second stage. The third is the determination of pectin content, followed by the lignin content in the fourth stage. The last stage is the separation of the holocellulose to obtain hemicellulose and cellulose. The Fourier transform infrared spectroscopy (FTIR) was undertaken for raw untreated banana fibre, and the $6 \%$ treated banana fibre only. The test was conducted using a Bruker Opus 8.7 model of spectroscopy apparatus.

\section{Experimental results and analysis}

\subsection{Physical and mechanical properties of single banana fibre strands}

Treated and untreated single banana fibre strands were subjected to a single fibre test, presented in Table 7. Results from the tests specify the effect of $\mathrm{NaOH}$ treatment at different $\mathrm{NaOH}$ concentration percentages on the properties of the single fibres. Physical properties such as fibre length were almost constant for each selected sample of single fibres. Nevertheless, treated banana fibres experience an increase in density compared to untreated fibres as the concentration of $\mathrm{NaOH}$ treatment increases. Meanwhile, the fibre diameter experienced a gradual decrease as the percentage of $\mathrm{NaOH}$ concentration increased in the treatment. The reduction in the fibre diameter also caused an increase in the single fibre aspect ratio; the fibre length remained constant while the diameter was reduced. The decrease in the diameter of a single fibre was attributed to the continuous increase in cleaning and washing of hemicellulose, lignin and pectin from the surfaces of the crystalline cellulose fibre as the concentration of $\mathrm{NaOH}$ increased. However, there was an improvement in the mechanical properties such as tensile strength, modulus of fracture and elongation at break of the single fibres as the percentage of $\mathrm{NaOH}$ concentration used in the fibre treatment increased. The increment reached its peak at $6 \% \mathrm{NaOH}$ treatment and began to decrease when the treatment had $8 \%$ and $10 \% \mathrm{NaOH}$ fibre treatments. The increment in mechanical properties was due to the influence of $\mathrm{NaOH}$ in cleaning the lignin, hemicellulose and other amorphous impurities on the fibre surfaces.

This cleaning facilitated the rearrangement of the microfibrils along the direction of tensile deformation and subsequent increase in tensile strength, young modulus and elongation at break. The reduction in mechanical properties at $8 \%$ and $10 \%$ $\mathrm{NaOH}$ concentration was due to over-cleaning the fibre surface by the higher concentration of $\mathrm{NaOH}$ solution, which damaged some of the microfibrils and cellulose cells and a subsequent reduction in strength. This finding is similar to work conducted by Oushabi et al. (2017), in which it was found that 5\% alkali concentration was the optimum for date palm fibre. Shanmugasundaram \& Rajendran (2016) reported a peak increase in tensile strength of mulberry fibre (605.61 MPa compared to untreated $463.84 \mathrm{MPa}$ ) at $5 \% \mathrm{NaOH}$ treatment, while tensile strength decreases from the peak at $10 \%$ and $15 \% \mathrm{NaOH}$ treatment. Similar findings were recorded (Borchani, Carrot, \& Jaziri, 2015; Cai et al., 2015; Reddy, Reddy, Zhang, Zhang, 
\& Rajulu, 2017)

Table 7. Single fibre properties of treated and untreated banana fibres.

\begin{tabular}{|c|c|c|c|c|c|c|}
\hline \multirow[b]{2}{*}{ Percentage $\mathrm{NaOH}$ treatment } & \multicolumn{6}{|c|}{ Physical and mechanical properties of single fibres } \\
\hline & $\begin{array}{l}\text { Outer di- } \\
\text { ameter } \\
(\mathrm{mm})\end{array}$ & $\begin{array}{l}\text { Density } \\
\left(\mathrm{g} / \mathrm{cm}^{3}\right)\end{array}$ & $\begin{array}{l}\text { Fibre length } \\
(\mathrm{mm})\end{array}$ & $\begin{array}{l}\text { Tensile } \\
\text { strength } \\
(\mathrm{MPa})\end{array}$ & $\begin{array}{l}\text { Modulus of } \\
\text { elasticity } \\
(\mathrm{GPa})\end{array}$ & $\begin{array}{c}\text { Elongation } \\
\text { at break }(\%)\end{array}$ \\
\hline $\mathrm{O} \% \mathrm{NaOH}$ treatment & 0.231 & 1.35 & 30 & 166 & 14.3 & 2.5 \\
\hline $2 \% \mathrm{NaOH}$ treated fibre & 0.229 & 1.38 & 30 & 231 & 17.4 & 4.9 \\
\hline $4 \% \mathrm{NaOH}$ treated fibre & 0.211 & 1.42 & 30 & 258 & 21.5 & 7.6 \\
\hline $6 \% \mathrm{NaOH}$ treated fibre & 0.189 & 1.45 & 30 & 487 & 28.7 & 11.1 \\
\hline $8 \% \mathrm{NaOH}$ treated fibre & 0.166 & 1.47 & 30 & 299 & 19.4 & 6.6 \\
\hline $10 \% \mathrm{NaOH}$ treated fibre & 0.148 & 1.51 & 30 & 221 & 11.6 & 5.2 \\
\hline
\end{tabular}

\subsection{Workability of fresh BFRCLC}

When the fibre was added to the fresh mortar mix, the workability of cement-sand mortar decreased. Results obtained through the flow table test indicate a sharp decrease in workability of the fresh plain control sample of the concrete composite compared to untreated fibre reinforced CLC samples, as shown in Fig. 4. This was due to the hydrophilic nature of the untreated banana fibre surfaces and hydroxyl group compounds, resulting in excessive water absorption and the subsequent reduction in workability of the untreated BFRCLC. The workability of the fresh untreated BFRCLC mix is lower than the workability of all the treated banana fibre reinforced composites. The main factor contributing to this variation is similar in the case of plain CLC since untreated banana fibre has high hemicellulose and lignin content. The hydroxyl group content was also higher, resulting in higher moisture absorption than treated fibres at various treatment percentages. Treated banana fibres lost a lot of hemicellulose and lignin and absorbed less water than untreated. Thus, the workability of the untreated banana fibre composites was much lower than that of the treated (Andiç-Çakir, Sarikanat, Tüfekçi, Demirci, \& Erdoğan, 2014). The degree of treatment also influenced water absorption and workability. Fibres with a high percentage of $\mathrm{NaOH}$ treatment absorbed less water. Hence, they exhibited higher workability than fibres with a lower percentage of $\mathrm{NaOH}$ treatment, which absorbed more water and exhibited higher water absorption.

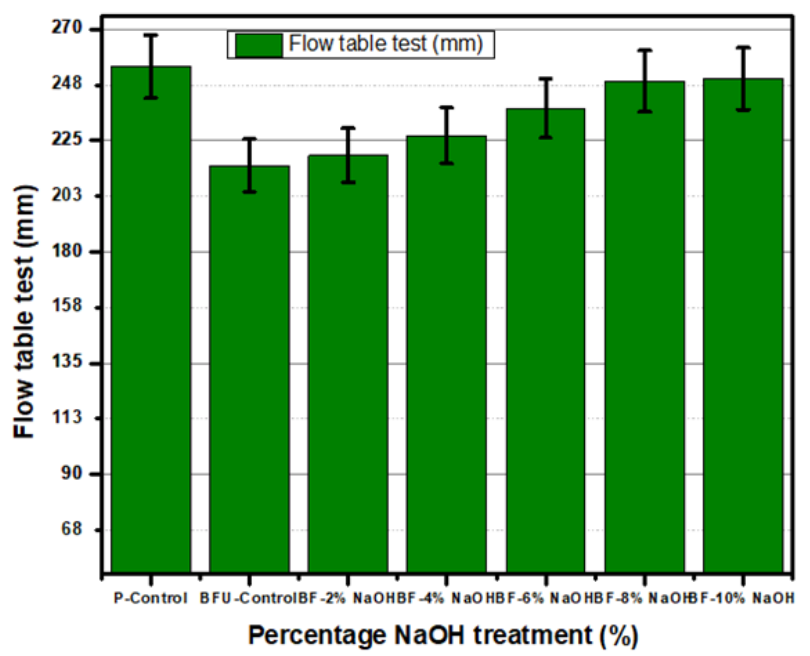

Figure 5. Results of fresh workability properties of treated and untreated BFRCLC

\subsection{Compressive strength of BFRCLC}

The results for the compressive strength of BFRCLC are shown in Table 3 and illustrated in Fig. 5. From Table 8 and Fig. 6, it will be noted that compressive strength increased with a rise in the hydration periods at all $\mathrm{NaOH}$ alkali percentage treatments. Results also indicate that CLC reinforced with untreated or alkali-treated banana fibres gave better compressive strength than the control plain CLC (unreinforced) (Kavitha et al., 2020). Findings show that alkali-treated CLC, irrespective 
of the percentage of $\mathrm{NaOH}$ fibre treatment, performs better in compressive strength than untreated banana fibre CLC (Mahzabin et al., 2018; Yan, Chouw, Huang, \& Kasal, 2016). Results from Table 3 and Fig. 6 also indicate a continuous increase in compressive strength compared to untreated fibre composites and plain CLC, increasing banana fibre alkali treatment.

At $2 \%$ and $4 \% \mathrm{NaOH}$ treatment, there was an improvement in compressive strength compared to the two control specimens, as better fibre surface treatment was achieved. This improvement continued progressively up to $6 \% \mathrm{NaOH}$ treatment of the fibre, where the compressive strength reached its peak strength. At $6 \% \mathrm{NaOH}$ treatment and 28 days curing age, the percentage increase in compressive strength was $40.6 \%$ and $59.8 \%$ to the untreated fibre composite and plain-control specimen, respectively. This high improvement in compressive strength resulted from the effective breakdown of the hydrogen bond between the hydroxyl groups (-OH) of lignin and hemicellulose from cellulose cells. The breaking of the bonds resulted in defibrillation, which broke bundles of fibres into smaller fibrillates (Pao \& Yeng, 2019). These changes increased the effective surface areas of fibres in the cement matrix. It also increased the efficient load transfer between the cement matrix and the reinforcing fibres. This was also physically demonstrated from the mode of deformation of the composite cubes reinforced with $6 \% \mathrm{NaOH}$ treated fibre compared to $4 \%$ and $8 \% \mathrm{NaOH}$ treated composites as shown in Fig. $6(\mathrm{a})$ - $4 \% \mathrm{NaOH}$, Fig. $6($ b) $-6 \% \mathrm{NaOH}$ and Fig. 6(c) $-8 \% \mathrm{NaOH}$ treated composites.

At $8 \%$ and $10 \% \mathrm{NaOH}$ treated composites, the percentage increase in compressive strength gradually declined to $6 \%$ $\mathrm{NaOH}$ treated composites. At $8 \%$ and $10 \% \mathrm{NaOH}$ treatment of the banana fibre, the percentage increase in strength compared to the untreated fibre composites and plain control CLC at 28 days curing age was $8 \% \mathrm{NaOH}-(20.1 \%)(36.5 \%)$ and $10 \% \mathrm{NaOH}-(10.8 \%)(26.0 \%)$ respectively. These increments were lower than those experienced by $6 \% \mathrm{NaOH}(40.6 \%)(59.8 \%)$ for both untreated and plain control samples. The main factor contributing to the decrease in the percentage increment at $8 \%$ and $10 \% \mathrm{NaOH}$ concentration was the over-cleaning of banana fibre surfaces caused by the high concentration of the $\mathrm{NaOH}$ solution(Cai et al., 2015; Sahu \& Gupta, 2020). Over-cleaning of cellulose fibres damaged and destroyed the cellulose surface, resulting in weak interfacial interactions between the fibre and the cement matrix. Similar trends of percentage increment in compressive strength were experienced at 56 days of curing age and various percentage $\mathrm{NaOH}$ treatments of the banana fibres. Hence, optimum compressive strength was experienced at $6 \% \mathrm{NaOH}$ treatment of the fibre. This result was similar to the findings by (Musa et al., 2019) and related to $\mathrm{NaOH}$ treatment of oil palm empty fruit bunches and coconut fibre, respectively.

Table 8. Variations of compressive strength of BFRCLC with $\mathrm{NaOH}$ treatment.

\begin{tabular}{lllll}
\hline \multicolumn{4}{l}{ BFRCLC batches } & \multicolumn{4}{l}{ Compressive strength at various curing ages (MPa) } \\
\hline Batch No. & Code & 7 Days & 28 Days & 56 Days \\
\hline 1 & P-control & $3.40(0)(-10.5)^{*}$ & $5.20(0)(-12.0)^{*}$ & $5.81(0)(-12.2)^{*}$ \\
2 & BFU-control & $3.80(11.8)(0)^{*}$ & $5.91(13.7)(0)^{*}$ & $6.62(13.9)(0)^{*}$ \\
3 & BF- $2 \% \mathrm{NaOH}$ & $4.00(17.6)(5.3)^{*}$ & $6.11(17.5)(3.4)^{*}$ & $6.72(15.7)(1.5)^{*}$ \\
4 & $\mathrm{BF}-4 \% \mathrm{NaOH}$ & $4.60(35.3)(21.1)^{*}$ & $6.80(30.8)(15.1)^{*}$ & $7.10(22.2)(7.3)^{*}$ \\
5 & $\mathrm{BF}-6 \% \mathrm{NaOH}$ & $6.90(102.9)(81.6)^{*}$ & $8.31(59.8)(40.6)^{*}$ & $8.60(48.0)(29.9)^{*}$ \\
6 & $\mathrm{BF}-8 \% \mathrm{NaOH}$ & $5.40(58.8)(42.1)^{*}$ & $7.10(36.5)(20.1)^{*}$ & $7.90(35.9)(19.3)^{*}$ \\
7 & $\mathrm{BF}-10 \% \mathrm{NaOH}$ & $5.70(67.6)(50.0)^{*}$ & $6.55(26.0)(10.8)^{*}$ & $6.71(15.5)(1.4)^{*}$ \\
\hline
\end{tabular}

$(0)=$ the value inside the brackets after the compressive strength reading denotes percentage increase in compressive strength with respect to the plain control CLC. $(-10.5)^{*}=$ The second brackets with Asterix denote the percentage increase in compressive strength with respect to the untreated control BFRCLC composites 


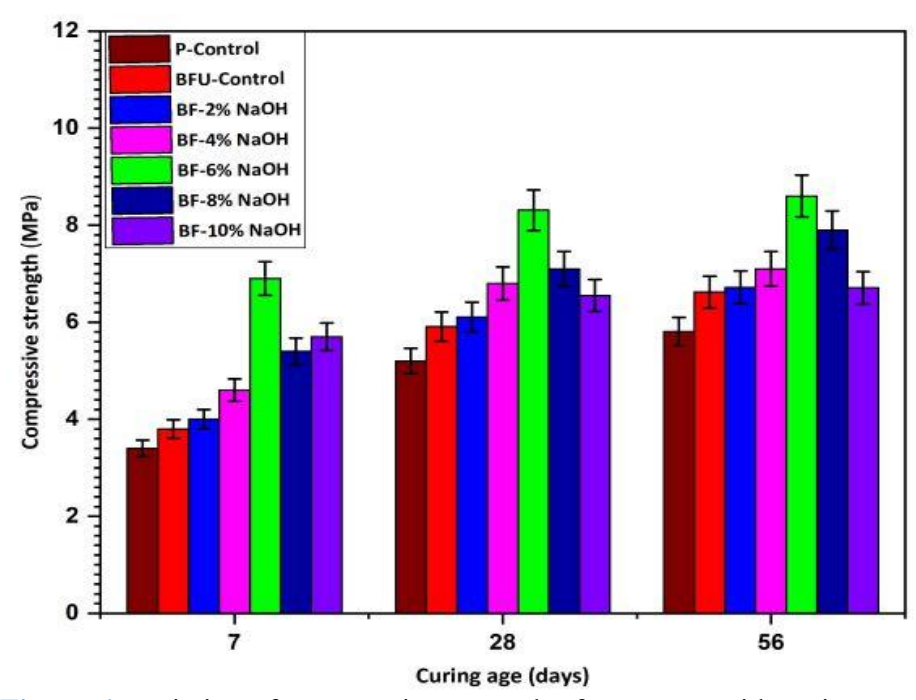

Figure 6. Variation of compressive strength of BFRCLC with curing age.

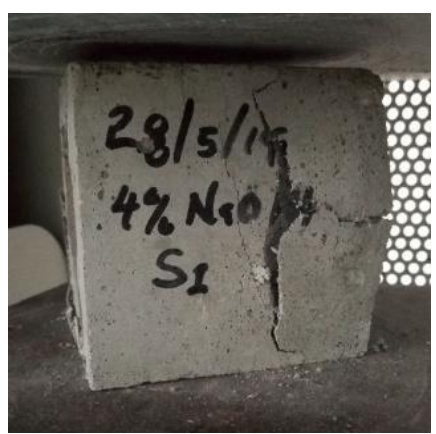

(a)

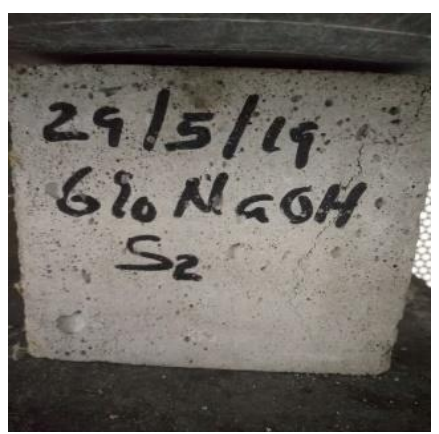

(b)

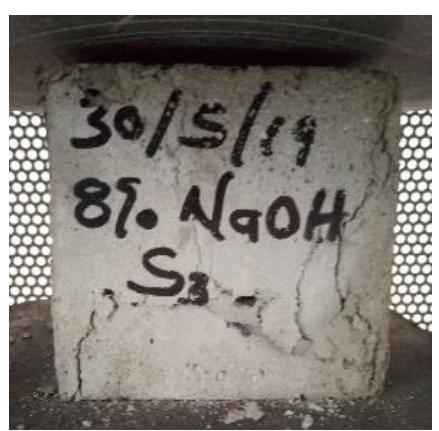

(c)

Figure 7. Failure patterns under compression (a) $4 \% \mathrm{NaOH}$; (b) $6 \% \mathrm{NaOH}$; (c) $8 \% \mathrm{NaOH}$

\subsection{Flexural strength of BFRCLC}

The results of the flexural strength of treated and untreated BFRCLC compared to the control plain CLC is given in Table 4 and illustrated in Fig. 7. Results from Table 4 and Fig. 7 indicate that irrespective of $\% \mathrm{NaOH}$ concentration treatment, the flexural strength of composites increased with an increase in the hydration periods. Similar to results obtained in the compressive strength test, BFRCLC composites, whether untreated or treated with $\mathrm{NaOH}$, performed better in flexural terms compared to the control plain CLC which was unreinforced. This finding was similar to the work of Ramli, Kwan and Abas (2013), who recorded improvements in the flexural strength of coconut fibre compared to plain concrete. Fibres, whether treated or untreated, assist in bridging and transmitting bending stress in the beam matrix. Fibres also aid in post crack deformation of composites members. In addition, all $\mathrm{NaOH}$ treated BFRCLC composites demonstrated better flexural strength than BFRCLC reinforced with the untreated banana fibres (Akinyemi \& Dai, 2020; Andiç-Çakir et al., 2014; Quiroga, Marzocchi, $\&$ Rintoul, 2016). The result also showed similar trends of changes in flexural strength as described in the section covering the compressive strength results.

There was a continuous increase in the flexural strength of BFRCLC composites from $2 \% \mathrm{NaOH}$ treatment to $10 \%$ $\mathrm{NaOH}$, with the highest flexural strength increase experienced at $6 \% \mathrm{NaOH}$ treatment of the fibres compared to the two controls (untreated fibre and plain CLC samples). The percentage increases in flexural strength for untreated fibre and plaincontrol samples were respectively $63.8 \%$ and $117.4 \%$, which slightly declined at $8 \% \mathrm{NaOH}$ treatment to $44.6 \%$ and $91.8 \%$, and declined at $10 \% \mathrm{NaOH}$ to $19.2 \%$ and $58.2 \%$, all at 28 days curing age. The reasons for these declines in strength from $6 \% \mathrm{NaOH}$ treatment to $10 \% \mathrm{NaOH}$ treatment were due to over-washing of fibre surface due to the high concentration of $\mathrm{NaOH}$ solution as explained above. Hence, $6 \% \mathrm{NaOH}$ concentration solution treatment of banana fibre produces the best 
flexural strength properties.

This is further buttressed by the mode of bending failure of the prismatic beam as shown in Fig. 8(a), (b), and (c), where the mode of fracture bending and crack deformation of beam reinforced with $4 \%$ and $8 \%$ treated $\mathrm{NaOH}$ concentration 8 (a), and $8(\mathrm{c})$ is higher compared to the mode of deflection of fibre reinforced composites treated with $6 \% \mathrm{NaOH}$ treatment $8(\mathrm{~b})$. This implies that at $6 \% \mathrm{NaOH}$ treatment, banana fibre surfaces were properly cleaned of lignin, pectin, hemicellulose and oils, thereby releasing microfibrils on the cellulose surface. The defibrillated microfibrils increased the surface area of the banana fibres, which improved the fibre surface adhesion with the cement matrix, thereby drastically reducing the tendency for cracks and excessive deflection under bending.

Othuman Mydin and Mohd Zamzani (2018) reported a peak increase in flexural strength at $6 \% \mathrm{NaOH}$ concentration treatment of coir fibre and a reduction from the peak at $4 \%, 8 \%$ and $10 \% \mathrm{NaOH}$ concentration. This differed from the $4 \% \mathrm{NaOH}$ treatment, where the cleaning of fibre surface of lignin, pectin, oils and hemicellulose was insufficient. Therefore, fibre surface adhesion with cement matrix was weak and resulted in the beam experiencing serious deflection and cracks. In the case of $8 \%$ treatment, the over-washing of fibre surfaces of lignin, pectin, oils and hemicellulose caused the fibre to degrade and lose its strength to transfer bending stress.

Table 9. Variations of flexural strength of BFRCLC with $\% \mathrm{NaOH}$ treatment.

\begin{tabular}{|lllll}
\hline \multicolumn{4}{l}{ BFRCLC Batches } & \multicolumn{3}{l}{ Flexural strength at various curing ages (MPa) } \\
\hline Batch No & Code & 7 days & 28 days & 56 days \\
\hline 1 & P-control & $0.59(0)(-45.9)^{*}$ & $0.98(0)(-24.6)^{*}$ & $1.12(0)(-22.2)^{*}$ \\
2 & BFU-control & $1.09(84.7)(0)^{*}$ & $1.30(32.7)(0)^{*}$ & $1.44(28.6)(0)^{*}$ \\
3 & BF-2\% NaOH & $1.14(93.2)(4.6)^{*}$ & $1.45(47.9)(11.5)^{*}$ & $1.51(38.4)(4.9)^{*}$ \\
4 & BF-4\% NaOH & $1.52(157.6)(39.4)^{*}$ & $1.68(71.4)(29.2)^{*}$ & $1.81(61.6)(25.7)^{*}$ \\
5 & BF-6\% NaOH & $2.01(240.7)(84.4)^{*}$ & $2.13(117.4)(63.8)^{*}$ & $2.61(133.0)(81.3)^{*}$ \\
6 & BF-8\% NaOH & $1.62(174.6)(48.6)^{*}$ & $1.88(91.8)(44.6)^{*}$ & $2.09(86.6)(45.1)^{*}$ \\
7 & BF-10\% NaOH & $1.29(118.6)(18.4)^{*}$ & $1.55(58.2)(19.2)^{*}$ & $1.61(43.8)(11.8)^{*}$ \\
\hline
\end{tabular}

$(0)=$ the value inside bracket after flexural strength reading denotes percentage increase in flexural strength with respect to the plain control CLC. $(-10.5)^{*}=$ The second brackets with Asterix denote the percentage increase in flexural strength with respect to the untreated control BFRCLC composites

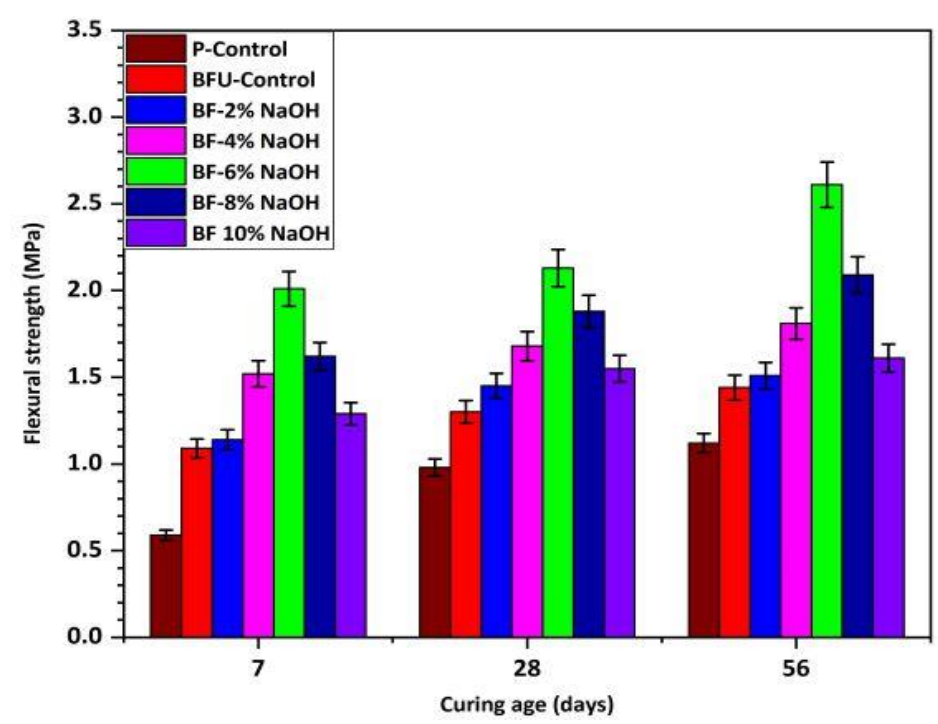

Figure 8. Variations of flexural strength of BFRCLC with curing age. 


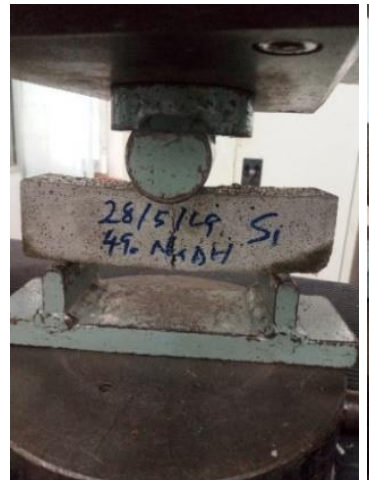

(a) $4 \% \mathrm{NaOH}$

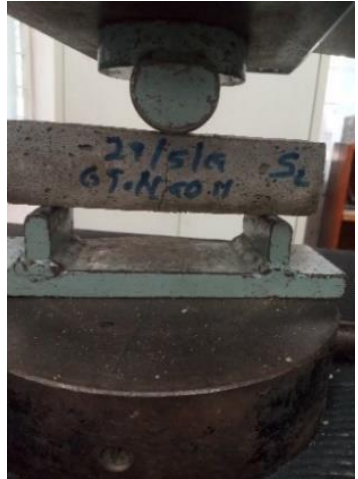

(b) $6 \% \mathrm{NaOH}$

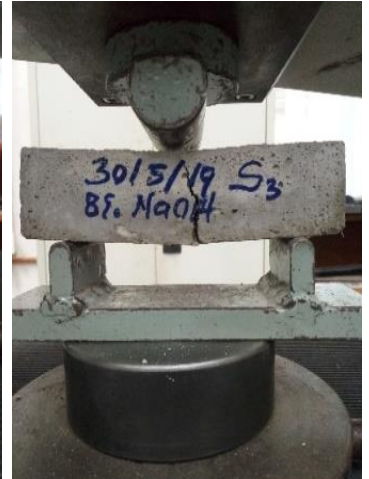

(c) $8 \% \mathrm{NaOH}$

Figure 9. Failure patterns under 3-point bending test

\subsection{Results of splitting tensile strength of BFRCLC}

Table 5 and Fig. 9 show the results of the splitting tensile strength of BFRCLC composites compared to the plain control CLC. Results indicate that each BFRCLC composite produced better splitting tensile strength than the plain control CLC, unreinforced. The study shows that the entire alkali-treated BFRCLC composites exhibited better tensile strength than the untreated BFRCLC composites (Ahmad, Hamid, \& Osman, 2019; Kavitha et al., 2020; Ozerkan, Ahsan, Mansour, \& Iyengar, 2013). Results from Table 5 and Fig. 9 indicate that the tensile strength of BFRCLC composites rose with an increase in the hydration periods for all percentage $\mathrm{NaOH}$ treatments. Compared to the untreated banana fibre control composites and plain CLC, the splitting tensile strength rose with an increase in percentage concentration of $\mathrm{NaOH}$ treatment of composites fibres up to $6 \% \mathrm{NaOH}$ treatment, where the tensile strength increment was the highest. The percentage increase in the tensile strength of BFRCLC composites at 28 days curing age and $6 \% \mathrm{NaOH}$ treatment was $77.4 \%$ and $157.8 \%$ compared to the untreated fibres control composites and plain CLC, respectively. At 28 days of curing age and compared to untreated fibre composites and plain control CLC, the percentage increase in tensile strength for $8 \% \mathrm{NaOH}$ was by $41.9 \%$ and $106.3 \%$, and for $10 \%$ $\mathrm{NaOH}$ treatment were by $-18.3 \%$ and $18.8 \%$. These percentage increases in tensile strength were far lower than in the $6 \%$ $\mathrm{NaOH}$ treated fibre composites. Hence, in terms of tensile strength, BFRCLC composites with $6 \% \mathrm{NaOH}$ treated fibres performed better than all the other banana fibre treated composites (Musa et al., 2019). Further clarification can be provided with the mode of splitting tensile failures of the destructive samples when tested in the laboratory, as shown in Fig. 10(a) to Fig. 10(c). Fig. 10(a) shows the crushed plain unreinforced control samples of the BFRCLC composites aged 28 days. The samples under splitting tensile stress were completely deformed by crushing into two equal parts, resembling the deformation shown by the $8 \% \mathrm{NaOH}$ treated fibre composites. However, $8 \% \mathrm{NaOH}$ treated fibre samples exhibited fewer crack openings compared to the unreinforced plain samples. The $6 \% \mathrm{NaOH}$ treated composites samples showed many minor cracks compared to the two samples under splitting tensile stress deformation.

Table 10. Variations of splitting tensile strength of BFRCLC with $\% \mathrm{NaOH}$ treatment.

\begin{tabular}{lllll}
\hline \multicolumn{4}{l}{ BFRCLC Batches } & \multicolumn{4}{l}{ Splitting tensile strength at various curing ages (MPa) } \\
\hline Batch No & Code & 7 days & 28 days & 56 days \\
\hline 1 & P-control & $0.37(0)(-39.3)^{*}$ & $0.64(0)(-31.2)^{*}$ & $0.72(0)(-31.4)^{*}$ \\
2 & BFU-control & $0.61(64.9)(0)^{*}$ & $0.93(45.3)(0)^{*}$ & $1.05(45.8)(0)^{*}$ \\
3 & $\mathrm{BF}-2 \% \mathrm{NaOH}$ & $0.69(86.5)(13.1)^{*}$ & $1.01(57.8)(8.6)^{*}$ & $1.07(48.6)(1.9)^{*}$ \\
4 & $\mathrm{BF}-4 \% \mathrm{NaOH}$ & $0.81(118.9)(32.8)^{*}$ & $1.03(60.9)(10.8)^{*}$ & $1.22(69.4)(16.2)^{*}$ \\
5 & $\mathrm{BF}-6 \% \mathrm{NaOH}$ & $1.31(254.1)(114.8)^{*}$ & $1.65(157.8)(77.4)^{*}$ & $1.78(147.2)(69.5)^{*}$ \\
6 & $\mathrm{BF}-8 \% \mathrm{NaOH}$ & $1.00(170.3)(63.9)^{*}$ & $1.32(106.3)(41.9)^{*}$ & $1.46(102.8)(39.1)^{*}$ \\
7 & $\mathrm{BF}-10 \% \mathrm{NaOH}$ & $0.50(35.1)(-18.0)^{*}$ & $0.76(18.8)(-18.3)^{*}$ & $0.80(11.1)(-23.8)^{*}$ \\
\hline the value inside the bracket after splitting tensile strength reading denotes percentage increase in splitting tensile strength with respect to the plain control CLC.
\end{tabular}

$(0)=$ the value inside the bracket after splitting tensile strength reading denotes percentage increase in splitting tensile strength with respect to the plain control $C$
$(-10.5) *=$ The second brackets with Asterix denote the percentage increase in splitting tensile strength with respect to the untreated control BFRCLC composites 


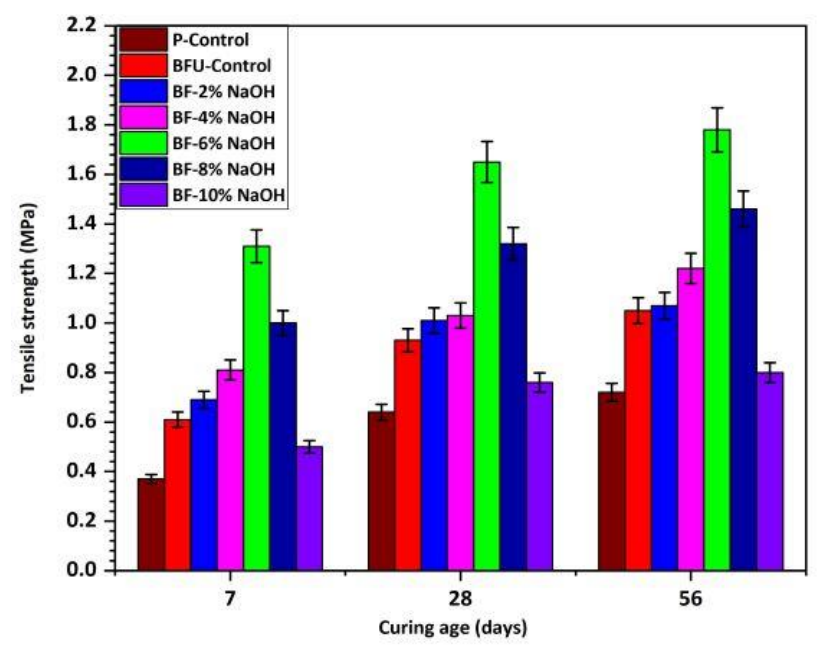

Figure 10. Variations of splitting tensile strength with curing age

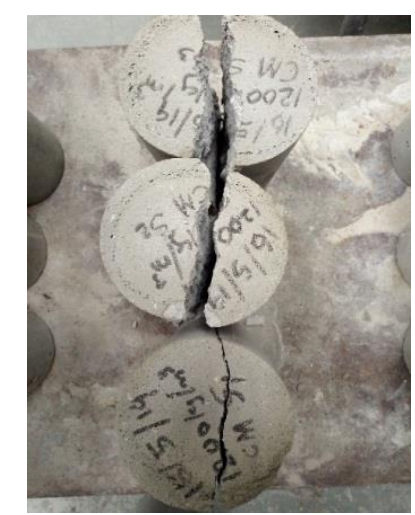

(a) plain CRC-Control

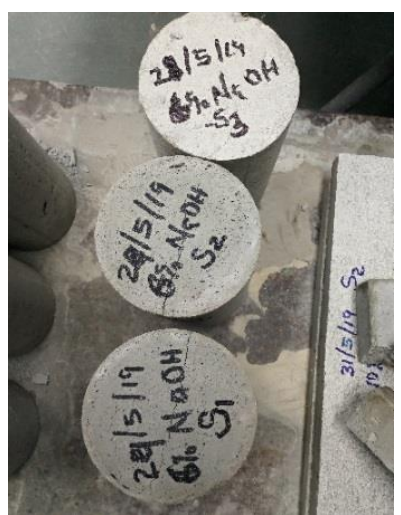

(b) $6 \% \mathrm{NaOH}$

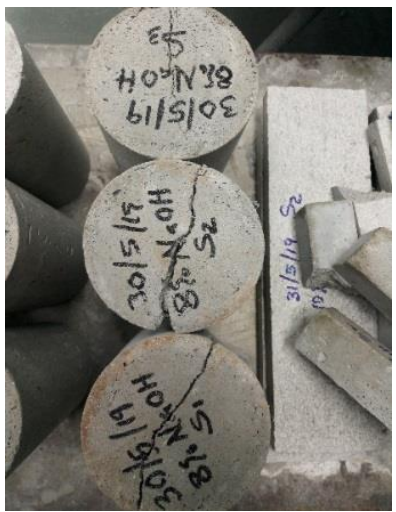

(c) $8 \% \mathrm{NaOH}$

Figure 11. Failure patterns under splitting tensile test.

\subsection{Results of ultra-sonic pulse velocity of BFRCLC composite}

The results of the ultrasonic pulse velocity of BFRCLC composites are given in Table 6 and Fig. 11. Results from Table 6 and Fig. 11 outline that the ultrasonic pulse velocity of BFRCLC increased with a rise in the hydration period of the composites irrespective of the percentage of $\mathrm{NaOH}$ treatment. In the same manner, compared to untreated composite samples and plain CLC samples, at the 28 days curing period, the ultrasonic pulse velocity increased with a larger percentage of $\mathrm{NaOH}$ treatment of banana fibre composite up to $6 \% \mathrm{NaOH}$ treatment, where the ultra-sonic pulse velocity was at its maximum values (Mydin, Mohamad, Samad, Johari, \& Munaaim, 2018). The percentage increase in the ultra-pulse velocity of the $6 \% \mathrm{NaOH}$ treated composites compared to the untreated composites samples and plain control samples at 28 days curing age were $14.1 \%$ and $15.3 \%$, respectively. This was higher than the percentage increase in the ultrasonic pulse velocity of $8 \% \mathrm{NaOH}-(10.6 \%)$ $(11.8 \%)$ and $10 \% \mathrm{NaOH}-(9.9 \%)(11.1 \%)$ treated composites samples compared to untreated composites and plain control samples, respectively. The slight reduction in percentage increase in the ultrasonic pulse velocity at $8 \%$ and $10 \% \mathrm{NaOH}$ treated composites was due to the high concentration of the alkali solution, which degraded the surfaces of treated fibres and reduced the fibre matrix adhesion of the composites. 
Table 11. Variations of ultra-sonic pulse velocity of BFRCLC with $\% \mathrm{NaOH}$ treatment.

\begin{tabular}{|c|c|c|c|c|}
\hline \multicolumn{2}{|c|}{ BFRCLC Batches } & \multicolumn{3}{|c|}{ Ultra-Sonic pulse velocity at various curing ages (MPa) } \\
\hline Batch No. & Code & 7 days & 28 days & 56 days \\
\hline 1 & P-Control & $1821(0)(-7.5)^{*}$ & $1960(0)(-1.1)^{*}$ & $1978(0)(-0.7)^{*}$ \\
\hline 2 & BFU-Control & $1968(8.1)(0)^{*}$ & $1981(1.1)(0)^{*}$ & $1991(0.7)(0)^{*}$ \\
\hline 3 & $\mathrm{BF}-2 \% \mathrm{NaOH}$ & $1989(9.2)(1.1)^{*}$ & $2015(2.8)(1.7)^{*}$ & $2021(2.2)(1.5)^{*}$ \\
\hline 4 & $\mathrm{BF}-4 \% \mathrm{NaOH}$ & $2101(15.4)(6.8)^{*}$ & $2156(10.0)(8.8)^{*}$ & $2161(9.3)(8.5)^{*}$ \\
\hline 5 & $\mathrm{BF}-6 \% \mathrm{NaOH}$ & $2237(22.8)(13.7)^{*}$ & $2260(15.3)(14.1)^{*}$ & $2370(19.8)(19.0)^{*}$ \\
\hline 6 & $\mathrm{BF}-8 \% \mathrm{NaOH}$ & $2186(20.0)(11.1)^{*}$ & $2191(11.8)(10.6)^{*}$ & $2193(10.9)(10.2) *$ \\
\hline 7 & $\mathrm{BF}-10 \% \mathrm{NaOH}$ & $2146(17.9)(9.1)^{*}$ & $2177(11.1)(9.9)^{*}$ & $2157(9.1)(8.3)^{*}$ \\
\hline
\end{tabular}

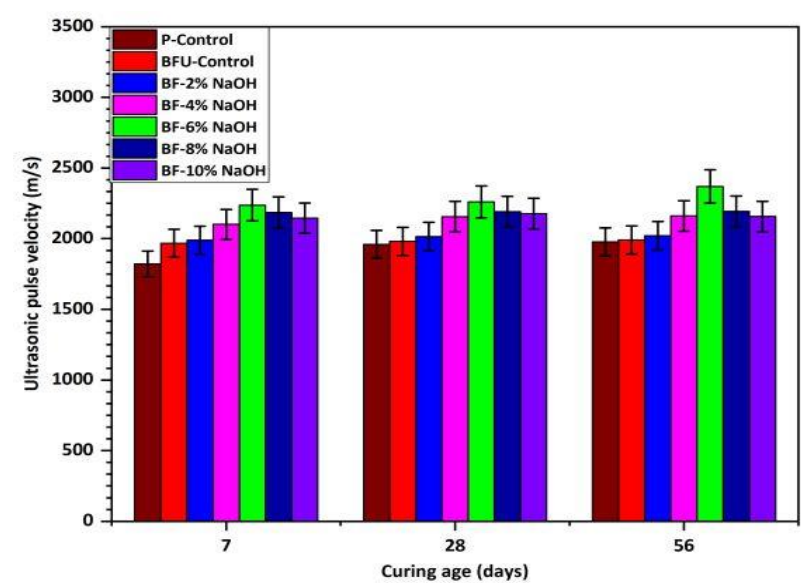

Figure 12. Ultra-sonic pulse velocity with $\% \mathrm{NaOH}$ treatment.

\subsection{Microstructural properties of treated and untreated banana fibre and its composites}

\subsubsection{Microstructure of the fibres}

Fig. 13 shows the micrograph images of banana fibre from the Scanning Electron Microscopy (SEM) assessment. The micrograph of raw banana fibres (untreated fibre), as shown in Fig. 13(a), is smooth, scaly and consists of crystalline cellulose embedded with amorphous hemicellulose lignin and pectin. With an increasing $\mathrm{NaOH}$ concentration, the diameter of the individual banana trunk fibres decreased. Microfibrils were inclined to amass easily when the cell wall lost lignin and hemicellulose, which might be partly responsible for the reduction in the diameter of fibre with the alkali treatment at higher concentrations in Fig. 13(b). After 6\% $\mathrm{NaOH}$ concentration treatment, the smooth raw fibre surface became rougher, as shown in Fig. 13(c). The roughness created was due to the removal from the fibre surface of the amorphous components of the fibres, which are hemicellulose, lignin, pectin and waxes. The removal of these components of the fibres defibrillated the microfibrils in the cellulose surfaces and therefore made the fibre surface rougher and increased the surface area, as seen in Fig. 13(c) (Borchani et al., 2015; Chandrasekar, Ishak, Sapuan, Leman, \& Jawaid, 2017). The rough surfaces created due to microfibrils improved the interfacial surface adhesion of the fibre with the cement matrix, thereby improving the mechanical properties of treated banana fibre composites compared to the untreated banana fibre composites.

In addition, removing hemicellulose, lignin and waxes from fibre surfaces reduced the hydroxyl components of the otherwise untreated fibres and thereby reduced the hydrophilic nature of fibre surfaces, leading to reduced water absorption. This also improved the excessive water absorption of alkali-treated banana fibre and enhanced the workability of the fresh mix and good adhesion properties between the fibre surface and the cement matrix. The higher the concentration of $\% \mathrm{NaOH}$ treatment on the banana fibre, the higher the degree of surface washing of the hemicellulose, lignin and waxes on the fibre micrograph and therefore, the rougher the surface of the banana, as evident from the micrograph $10 \% \mathrm{NaOH}$ treatment of banana fibre in Fig. 13(d). However, such over-washing resulted in the surface degradation or mineralisation of the cellulose fibres (Hashim, Amin, Mohd, \& Marwah, 2017; Shanmugasundaram \& Rajendran, 2016). 
This finding from the microstructural SEM analysis supports the results outlined by all the mechanical properties identified in terms of compressive, flexural and splitting tensile strength of the CLC composites produced with varying percentage concentrations of $\mathrm{NaOH}$ treated and untreated fibres. It also supports the $6 \% \mathrm{NaOH}$ treatment of banana fibre since this percentage produced the best results.

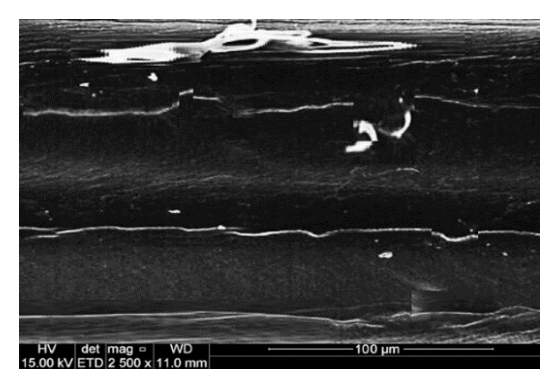

(a)

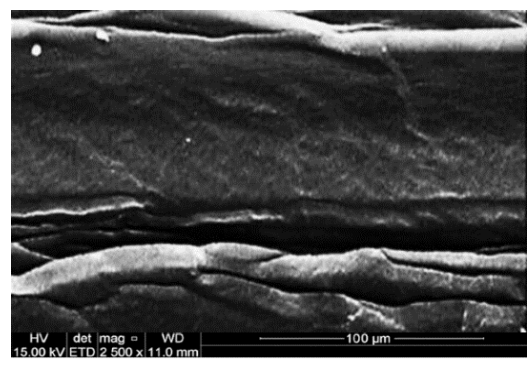

(c)

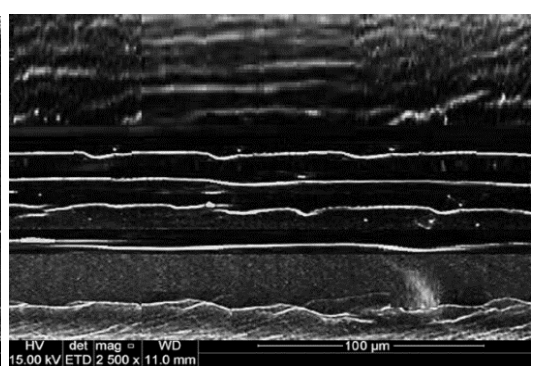

(b)

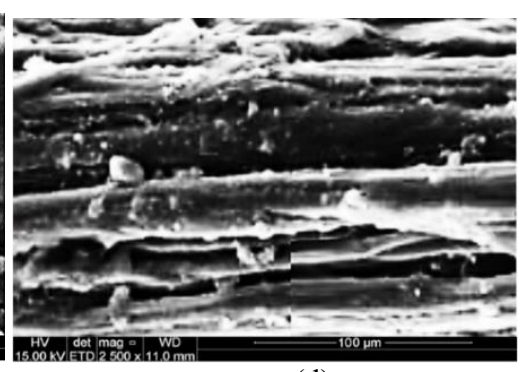

(d)

Figure 13. Micrograph images of banana fibre from the scanning electron microscopy (SEM) assessment (a) untreated banana fibre; (b) $2 \% \mathrm{NaOH}$ treatment; (c) $6 \% \mathrm{NaOH}$ treatment; (d) $10 \% \mathrm{NaOH}$ treatment.

\subsubsection{Microstructure of the BFRCLC composites}

The BFRCLC composites micrograph obtained from SEM analysis is shown in Figure 14. Figure 14(a) is the SEM micrograph of untreated BFRCLC composite at 120 magnifications, displaying numerous uneven macropore or air voids. Some of the air voids are merged, resulting in very large merged macropores responsible for the poor mechanical properties obtained in the compressive, flexural, and tensile strength results compared to composites reinforced with alkali-treated banana fibres. In addition, the untreated banana fibre shown in Figure 14 (a) is scaly, displaying the smooth scaly surface as shown in figure 12 (a). This is evidence of a lack of good interfacial bonding between the cement matrix and the fibre surface (Nensok et al., 2021). This is also responsible for poor load transfer during mechanical loading in the composite of untreated fibre.

In contrast, Figure 14(b) display the SEM micrograph of $6 \% \mathrm{NaOH}$ treated BFRCLC composite at 120 magnifications. The hydrated C-S-H gel completely covers the 6 per cent $\mathrm{NaOH}$ treated banana fibre in the composite, making the fibre surface appear smooth. This is seen in Figure 13(c), an SEM micrograph with 10000 magnifications of the same treated banana fibre shown in Figure 13(b). The high magnifications of treated banana fibre demonstrate how C-H-S gel fully encapsulated the alkali-treated banana fibre, resulting in an excellent interfacial bond between the cement matrix and the roughly treated banana fibre surface. This is responsible for uniform stress distribution in the composite. It is important to note that both micrographs exhibited uneven macropores. However, the uneven macropore is much in the composite with untreated banana fibre.

Similarly, the composite with untreated banana fibre displays numerous numbers of micropores, while its counterpart shows very few presences of micropores. This could be attributed to the difference in w/s ratio during mixing since there is no superplasticiser used. Untreated banana fibre absorbs more water than treated banana fibre to reach the required consistency at a fresh state. As shown in the micrograph, this causes the untreated banana fibre composites to be more pervious and porous, 
resulting in a decrease in strength compared to the treated banana fibre composite (Mahzabin et al., 2018).

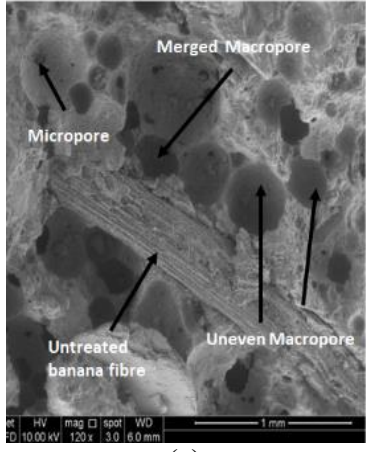

(a)

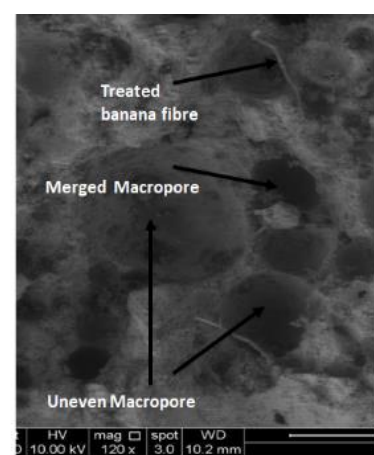

(b)

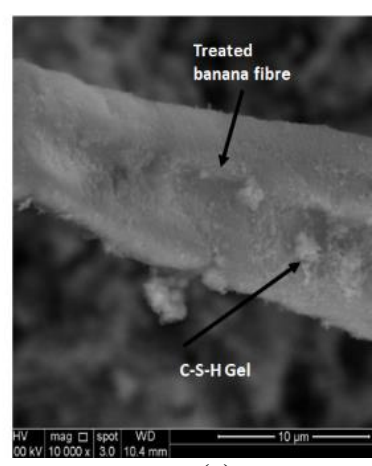

(c)

Figure 14. Micrograph images of treated and untreated banana fibre composites (a) untreated composites 120x; (b) treated composite $120 x$; treated fibre $10000 x$.

\subsection{Chemical compound analysis (FTIR) for treated and untreated BF}

The transmittance band and their positions were studied in the 4000 to $500 \mathrm{~cm}^{-1}$ for untreated and $6 \% \mathrm{NaOH}$ treated banana fibres using FTIR spectrum. Table 12 depicts the FTIR peaks of the raw BF, and $6 \%$ treated banana fibres. Figure 15 also display the FTIR spectrum of the raw and treated BF. The results from the table and graphs depict a reduction in peaks at the broadband $3429.5 \mathrm{~cm}^{-1}$ (raw BF) to $3408.2 \mathrm{~cm}^{-1}$ (treated BF) which represents hydroxyl groups for hydrogen bonds of hemicellulose and fats (Pao \& Yeng, 2019; Shanmugasundaram \& Rajendran, 2016). A similar reduction of the C-H bonds was experienced at the transmittance of $2933.8 \mathrm{~cm}^{-1}$ (raw BF) to $2912.5 \mathrm{~cm}^{-1}$ (treated BF) (Sango et al., 2018). This is attributed to the cleaning of wax, pectin and fats by $6 \% \mathrm{NaOH}$ on the surfaces of the raw BF. The cleaning of such impurities from untreated $\mathrm{BF}$ is responsible for improved fibre matrix adhesion or bonding. At the $\mathrm{C}=\mathrm{O}$ bond stretching relating to the hemicellulose group, a reduction in the peak transmittance is also observed from $1648.4 \mathrm{~cm}-1$ (untreated BF) to $1627.1 \mathrm{~cm}^{-1}(6 \%$ $\mathrm{NaOH}$ treated BF) (Neto et al., 1996; Shanmugasundaram \& Rajendran, 2016). The peak at 1320.1 (raw fibre) and 1306.2 ( $6 \%$ treated fibre) indicates the deformation of cellulose and hemicellulose $(\mathrm{C}-\mathrm{H}$ bond) (Akinyemi, Omoniyi, \& Onuzulike, 2020; Chandrasekar et al., 2017). In comparison, the fingerprints peak at $1062.4 \mathrm{~cm}^{-1}$ (raw BF) and 1041.0 (treated BF) is associated with the deformation of cellulose and lignin due to alkali treatment (Shanmugasundaram \& Rajendran, 2016).

The last bond (O-H stretching) is associated with the presence of lignin components of the hydroxyl group with a transmittance peak at $636.4 \mathrm{~cm}^{-1}$ (untreated $\mathrm{BF}$ ) and $601.1 \mathrm{~cm}^{-1}(6 \%$ treated $\mathrm{BF}$ ). In the first and last cases of the peak transmittance, $6 \%$ alkali treatment of $\mathrm{BF}$ resulted in the reduction of hydrogen bond $(\mathrm{O}-\mathrm{H})$ between the hydroxyl groups $(-\mathrm{OH})$. The reduction was responsible for the defibrillation of multiple bundles of fibrils to fibrillates as seen in the SEM micrographs in Figure 13 (c)., and results in the increased surface areas for improved cement matrix bonding as illustrated in Figure 14 (b) and (c), which leads to the improved mechanical properties of $6 \% \mathrm{NaOH}$ treated composites compared to the untreated and overtreated alkali composites ( $8 \%$ and $10 \%)$. This finding corroborates with the result of chemical deconstruction given in Table 5 to elaborate the influence of $\mathrm{NaOH}$ treatment in reducing amorphous hemicellulose, lignin, wax and impurities from the $\mathrm{BF}$ surfaces while the crystalline cellulose percentage increases.

Table 12. FTIR peaks of treated and untreated banana fibre.

\begin{tabular}{llll}
\hline & Wavenumber $\left(\mathrm{cm}^{-1}\right)$ & \\
\cline { 2 - 4 } Bond type & Untreated BF $(\mathrm{Raw} \mathrm{BF})$ & Treated BF $(6 \% \mathrm{NaOH})$ & Remarks \\
\hline O-H stretching & 3429.5 & 3408.2 & $\begin{array}{l}\text { Stretching of hydrogen bond of hemicellu- } \\
\text { lose and fats }\end{array}$ \\
& & & Modes of methyl and methylene groups \\
C-H vibration & 2933.8 & 2912.5 & Stretch of acetyl group of hemicellulose \\
C=O stretching & 1648.4 & 1627.1 & Cellulose and hemicellulose deformation \\
C-H deformation & 1320.1 & 1306.2 & Cellulose and lignin deformation \\
Si-O stretching & 1062.4 & 1041.0 & Lignin deformation \\
O-H stretching & 636.4 & 601.1 & \\
\hline
\end{tabular}




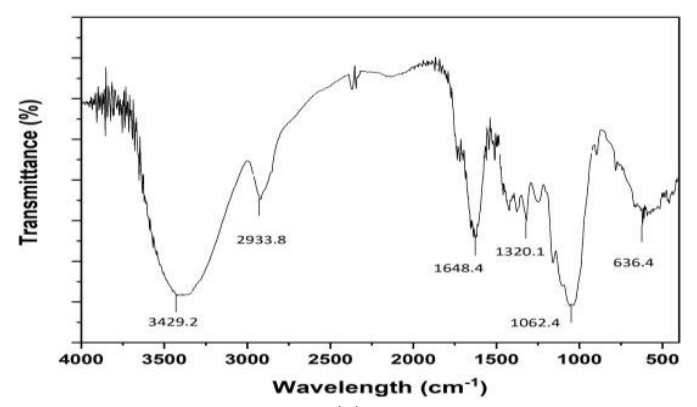

(a)

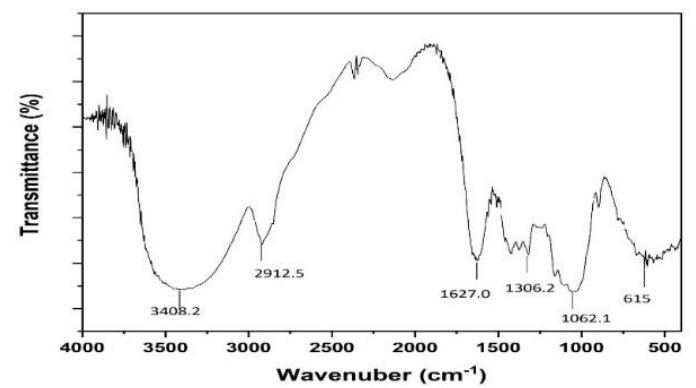

(b)

Figure 15. FITR spectrum for untreated and treated BF (a) raw BF (untreated BF); (b) $6 \%$ treated BF.

\section{Conclusions and comments}

This study investigated the influence of different percentage concentrations of $\mathrm{NaOH}(2 \%, 4 \%, 6 \%, 8 \%$ and $10 \%)$ in the treatment of banana fibre and its effects on mechanical properties of the single banana fibre and BFRCLC composites. An outline of the findings from the various tests conducted is summarised as follows:

1. The chemical deconstruction technique of banana fibre depicts that cellulose concentration increases while hemicellulose and lignin content decreases with increased alkali concentration in the treatment. This is caused by the ability of the $\mathrm{NaOH}$ to remove the amorphous component of the fibre while the crystalline cellulose remains insoluble.

2. Treatment of banana fibre surfaces with different concentrations of $\mathrm{NaOH}$ solutions increases tensile strength, modulus of elasticity and elongation at break. This was due to the rearrangement of the microfibrils in the direction of tensile deformation and an increase in aspect ratio, which was caused by cleaning the fibre surfaces of debris, impurities and amorphous components of the fibres. For the same reasons, the single fibre experienced a reduction in diameter and an increment in density.

3. The incorporation of alkali-treated and untreated banana fibre in CLC resulted in a decrease in the workability of fresh composites. The untreated banana fibre composite exhibited lower workability due to the high hydroxyl group (-OH) content compared to the treated BFRFCLC composites. Composites with a higher percentage of alkali treatment absorb less water and hence exhibited higher workability.

4. The introduction of alkali-treated banana fibre into CLC resulted in a peak increase in compressive strength at $6 \%$ $\mathrm{NaOH}$ concentration treatment of $40.6 \%$ and $59.8 \%$ for both untreated and plain control composites at 28 days. The increase in strength is because of the breakdown of the hydrogen bond between the hydroxyl groups, which resulted in the defibrillation of bundle fibres to fibrillates, thereby increasing the surface area of the fibres and culminating in improved load transfer between cement matrix and fibres.

5. There is also a peak increase in flexural strength at $6 \% \mathrm{NaOH}$ concentration treatment of the BFRFCLC composites of $63.8 \%$ and $117.4 \%$ compared to the untreated fibre composite and the plain control. 
6. A similar trend of peak percentage increments at $6 \% \mathrm{NaOH}$ concentration treatment was recorded for the splitting tensile strength of BFRCLC composites at 28 days of $77.4 \%$ and $157.8 \%$, compared to untreated fibre composites and plain CLC, respectively.

7. Results were also recorded for the ultrasonic pulse velocity test. The percentage increases in terms of non-destructive parameters at 28 days for a peak $6 \% \mathrm{NaOH}$ concentration treatment was by $14.1 \%$ and $15.3 \%$, compared to the untreated fibre composites and plain control CLC.

8. The results from SEM micrograph analysis of treated and untreated banana fibre surfaces and BFRCLC composites corroborates to vividly show the influence of the peak $6 \% \mathrm{NaOH}$ concentration treatment in the proper surface cleaning of banana fibres of hemicellulose, lignin, pectin and waxes, thereby creating a rougher surface due to defibrillation of bundle fibrils resulting in increased surface area. This leads to improved interfacial adhesion of fibre surfaces with cement matrix and subsequent improvement in compressive, flexural, tensile and pulse velocity properties.

9. FTIR analysis also corroborates with chemical deconstruction and SEM analysis to buttress alkali treatment's ability to enhance the mechanical performance of the BFRCLC composites.

10. To summarise these results, the study indicates that the optimum percentage treatment of banana fibre for use in CLC composites and to achieve the best mechanical properties was $6 \% \mathrm{NaOH}$ treatment.

11. As the present study only evaluates the influence of $\mathrm{NaOH}$ concentration treatment on the mechanical properties of BFRCLC composites, further studies on the influence of the $6 \% \mathrm{NaOH}$ alkali treatment on the durability properties of BFRCLC is recommended.

Author contributions: MNH, MAOM and HA were involved in the study; from laboratory work, data analysis, manuscript writing, to final confirmation.

Funding: Universiti Sains Malaysia.

Acknowledgments: The authors would Like to thank Universiti Sains Malaysia for their funding of this research through the Bridging Grant (304 / PPBGN / 6316230).

Conflicts of interest: We hereby declare that there is no conflict of interest in the publication of this article

\section{References}

Ahmad, R., Hamid, R., \& Osman, S. A. (2019). Physical and Chemical Modifications of Plant Fibres for Reinforcement in Cementitious Composites. Advances in Civil Engineering, 2019.

Aini, K., Sari, M., Rahim, A., \& Sani, M. (2017). Applications of Foamed Lightweight Concrete. MATEC Web of Conferences, 01097, 1-5.

Akinyemi, B. A., \& Dai, C. (2020). Development of banana fibers and wood bottom ash modified cement mortars. Construction and Building Materials, 241, 118041. https://doi.org/10.1016/j.conbuildmat.2020.118041

Akinyemi, B. A., Omoniyi, E. T., \& Onuzulike, G. (2020). Effect of microwave assisted alkali pretreatment and other pretreatment methods on some properties of bamboo fibre reinforced cement composites. Construction and Building Materials, $245,118405$. https://doi.org/10.1016/j.conbuildmat.2020.118405

Amran, M., Fediuk, R., Vatin, N., Lee, Y. H., Murali, G., Ozbakkaloglu, T., ... Alabduljabber, H. (2020). Fibre-reinforced foamed concretes: A review. Materials, 13(19), 1-36. https://doi.org/10.3390/ma13194323

Andiç-Çakir, Ö., Sarikanat, M., Tüfekçi, H. B., Demirci, C., \& Erdoğan, Ü. H. (2014). Physical and mechanical properties of randomly oriented coir fibercementitious composites. Composites Part B: Engineering, 61, 49-54. https://doi.org/10.1016/j.compositesb.2014.01.029

ASTM C 1557-14. (2014). Standard Test Method for Tensile Strength and Young's Modulus of Fibers. American Society for Testing and Material.

ASTM C348. (2020). Flexural strength of hydraulic-cement mortars. American Society for Testing and Material, 04, 1-6.

ASTM C496/ C496M-17. (2017). Standard Test Method for Splitting Tensile Strength of Cylindrical Concrete Specimen. American Society for Testing and Material., 1-5.

Awang, H., Ahmad, M. H., \& Al-Mulali, M. Z. (2015). Influence of kenaf and polypropylene fibres on mechanical and durability properties of fibre reinforced lightweight foamed concrete. Journal of Engineering Science and Technology, 10(4), 496-508. 
Awang, Hanizam, \& Ahmad, M. H. (2014). Durability properties of foamed concrete with fiber inclusion. International Journal of Civil, Structural, Construction and Architectural Engineering, 8(3), 273-276. Retrieved from https://www.researchgate.net/profile/Muhammad_Hafiz_Ahmad/publication/274848776_Durability_Properties_of_Foamed_Concrete_with_Fiber_Inclusion/links/552b5e070cf2779ab7930c6e/Durability-Properties-ofFoamed-Concrete-with-Fiber-Inclusion.pdf

Borchani, K. E., Carrot, C., \& Jaziri, M. (2015). Untreated and alkali treated fibers from Alfa stem: effect of alkali treatment on structural, morphological and thermal features. Cellulose, 22(3), 1577-1589. https://doi.org/10.1007/s10570-015-0583-5

BS EN 12390-2019 Part 3. (2019). Testing hardened concrete: Compressive strength of test specimens. British Standard Institute, 4-10.

BS EN 12504-4. (2004). Non-destructive Concrete Testing. British Standard Institute, 3875, 3877.

BS EN 197-1: 2011. (2011). Cement Part 1 : Composition, specifications and conformity criteria for common cements. British Standard Institute.

Cai, M., Takagi, H., Nakagaito, A. N., Katoh, M., Ueki, T., Waterhouse, G. I. N., \& Li, Y. (2015). Influence of alkali treatment on internal microstructure and tensile properties of abaca fibers. Industrial Crops and Products, 65, 27-35. https://doi.org/10.1016/j.indcrop.2014.11.048

Castillo-Lara, J. F., Flores-Johnson, E. A., Valadez-Gonzalez, A., Herrera-Franco, P. J., Carrillo, J. G., Gonzalez-Chi, P. I., \& Li, Q. M. (2020). Mechanical Properties of Natural Fiber Reinforced Foamed Concrete. Materials, 1-18.

Chandrasekar, M., Ishak, M. R., Sapuan, S. M., Leman, Z., \& Jawaid, M. (2017). A review on the characterisation of natural fibres and their composites after alkali treatment and water absorption. Plastic, Rubber and Compoistes, 46(3), 119-136. https://doi.org/10.1080/14658011.2017.1298550

Harith, I. K. (2018). Study on polyurethane foamed concrete for use in structural applications. Case Studies in Construction Materials, 8(September 2017), 79-86. https://doi.org/10.1016/j.cscm.2017.11.005

Hashim, M. Y., Amin, A. M., Mohd, O., \& Marwah, F. (2017). The effect of alkali treatment under various conditions on physical properties of kenaf fiber. Journal of Physics: Conference Series, 1-16.

Kavitha, S. M., Venkatesan, G., Avudaiappan, S., \& Saavedra Flores, E. I. (2020). Mechanical and flexural performance of self compacting concrete with natural fiber. Revista de La Construccion, 19(2), 370-380. https://doi.org/10.7764/RDLC.19.2.370

Madhwani, H., Sathyan, D., \& Mini, K. M. (2020). Study on durability and hardened state properties of sugarcane bagasse fiber reinforced foam concrete. Materials Today: Proceedings, (xxxx), 1-6. https://doi.org/10.1016/j.matpr.2020.10.313

Mahzabin, M. S., Hock, L. J., Hossain, M. S., \& Kang, L. S. (2018). The influence of addition of treated kenaf fibre in the production and properties of fibre reinforced foamed composite. Construction and Building Materials, 178, 518-528. https://doi.org/10.1016/j.conbuildmat.2018.05.169

Mohamad, N., Samad, A. A. A., Lakhiar, M. T., Mydin, M. A. O., Jusoh, S., Sofia, A., \& Efendi, S. A. (2018). Effects of incorporating banana skin powder (BSP) and palm oil fuel ash (POFA) on mechanical properties of lightweight foamed concrete. International Journal of Integrated Engineering, 10(9), 169-176. https://doi.org/10.30880/ijie.2018.10.09.013

Mohd Zamzani, N., Othuman Mydin, M. A., \& Abdul Ghani, A. N. (2019). Influence of caustic soda treatment on mechanical performance of ' cocos nucifera linn' fiber reinforced lightweight foam mortar. IOP Conference Series: Earth and Environmental Science, $220(1), 012042$. https://doi.org/10.1088/1755-1315/220/1/012042

Mostafa, M., \& Uddin, N. (2016). Experimental analysis of Compressed Earth Block (CEB) with banana fibers resisting fl exural and compression forces. Case Studies in Construction Materials, 5, 53-63. https://doi.org/10.1016/j.cscm.2016.07.001

Musa, M., Othuman Mydin, M. A., \& Abdul Ghani, A. N. (2019). Effect of lye alkaline solution treatment on engineering properties of oil palm empty fruit bunches (EFB) fiber strengthen foamed concrete. In IOP Conference Series: Earth and Environmental Science (Vol. 220, p. 012041). https://doi.org/10.1088/1755-1315/220/1/012041

Mydin, M. A. O., Mohamad, N., Samad, A. A. A., Johari, I., \& Munaaim, M. A. C. (2018). Durability performance of foamed concrete strengthened with chemical treated $(\mathrm{NaOH})$ coconut fiber. AIP Conference Proceedings, 2016(September). https://doi.org/10.1063/1.5055511

Mydin, M. A. O., Musa, M., \& Ghani, A. N. A. (2018). Fiber glass strip laminates strengthened lightweight foamed concrete: Performance index, failure modes and microscopy analysis. In AIP Conference Proceedings (Vol. 2016, p. 020111). American Institute of Physics. https://doi.org/10.1063/1.5055513

Mydin, M. A. O., Zamzani, N. M., \& Ghani, A. N. A. (2018). Effect of alkali-activated sodium hydroxide treatment of coconut fiber on mechanical properties of lightweight foamed concrete. In 3rd International Conference on Applied Science and Technology (Vol. 5055512, p. 020108). https://doi.org/10.1063/1.5055510

Nensok, M. H., Mydin, A. O., \& Awang, H. (2021). Investigation of Thermal, Mechanical and Transport Properties of Ultra-Lightweight Foamed Concrete ( ULFC ) Strengthened with Alkali Treated Banana Fibre. Journal of Advanced Research in Fluid Mechanics and Thermal Sciences, 1(1), 17-32.

Neto, C. P., Seca, A., Fradinho, D., Coimbra, M. A., Domingues, F., Evtuguin, D., ... Cavaleiro, J. A. S. (1996). Chemical composition and structural features of the macromolecular components of Hibiscus cannabinus grown in Po ... Industrial Crops and Products, 5, 169-196.

Othuman, A. M., Nabihah, M. Z., \& Naser, A. G. (2020). Influence of elevated temperatures on compressive and flexural strengths of Cocos nucifera Linn. fiber strengthened lightweight foamcrete. Revista de La Construccion, 19(1), 112-126. https://doi.org/10.7764/RDLC.19.1.112-126 
Othuman Mydin, M. A., \& Mohd Zamzani, N. (2018). Coconut fiber strengthen high performance concrete: Young's modulus, ultrasonic pulse velocity and ductility properties. International Journal of Engineering and Technology (UAE), 7(2), 284-287. https://doi.org/10.14419/ijet.v7i2.23.11933

Ozerkan, N. G., Ahsan, B., Mansour, S., \& Iyengar, S. R. (2013). Mechanical performance and durability of treated palm fiber reinforced mortars. International Journal of Sustainable Built Environment, 2(2), 131-142. https://doi.org/10.1016/j.ijsbe.2014.04.002

Pacheco-Torgal, F., \& Jalali, S. (2011). Cementitious building materials reinforced with vegetable fibres: A review. Construction and Building Materials, 25(2), 575-581. https://doi.org/10.1016/J.CONBUILDMAT.2010.07.024

Pakravan, H. R., Jamshidi, M., \& Latifi, M. (2016). The effect of hybridisation and geometry of polypropylene fibers on engineered cementitious composites reinforced by polyvinyl alcohol fibers. Journal of Composite Materials, 50(8), 1007-1020. https://doi.org/10.1177/0021998315586078

Pao, Z., \& Yeng, C. M. (2019). Properties and characterisation of wood plastic composites made from agro-waste materials and post-used expanded polyester foam. Journal of Thermoplastic Composite Materials, 32(7), 951-966. https://doi.org/10.1177/0892705718772877

Quiroga, A., Marzocchi, V., \& Rintoul, I. (2016). Influence of wood treatments on mechanical properties of wood-cement composites and of Populus Euroamericana wood fibers. Composites Part B: Engineering, 84, 25-32. https://doi.org/10.1016/J.COMPOSITESB.2015.08.069

Raj, A., Sathyan, D., \& Mini, K. M. (2019). Physical and functional characteristics of foam concrete: A review. Construction and Building Materials. https://doi.org/10.1016/j.conbuildmat.2019.06.052

Raj, B., Sathyan, D., Madhavan, M. K., \& Raj, A. (2020). Mechanical and durability properties of hybrid fiber reinforced foam concrete. Construction and Building Materials, 245. https://doi.org/10.1016/j.conbuildmat.2020.118373

Ramli, M., Kwan, W. H., \& Abas, N. F. (2013). Strength and durability of coconut-fiber-reinforced concrete in aggressive environments. Construction and Building Materials, 38, 554-566. https://doi.org/10.1016/J.CONBUILDMAT.2012.09.002

Reddy, K. O., Reddy, K. R. N., Zhang, J., Zhang, J., \& Rajulu, A. V. (2017). Effect of alkali treatment on the tensile properties of century fibers. Wool Textile Journal, 45(9), 48-51. https://doi.org/10.19333/j.mfkj.2016090120904

Risdanareni, P., Sulton, M., \& Nastiti, S. F. (2016). Lightweight foamed concrete for prefabricated house. AIP Conference Proceedings, 1778(2016). https://doi.org/10.1063/1.4965763

Sahu, P., \& Gupta, M. K. (2020). A review on the properties of natural fibres and its bio-composites: Effect of alkali treatment. Materials Design and Application, 234(1), 198-217. https://doi.org/10.1177/1464420719875163

Sango, T., Maxime, A., Yona, C., Duchatel, L., Marin, A., Kor, M., ... Lefebvre, J. (2018). Step - wise multi - scale deconstruction of banana pseudo - stem (Musa acuminata ) biomass and morpho - mechanical characterisation of extracted long fi bres for sustainable applications. Industrial Crops \& Products, 122(June), 657-668. https://doi.org/10.1016/j.indcrop.2018.06.050

Shanmugasundaram, N., \& Rajendran, I. (2016). Characterisation of raw and alkali-treated mulberry fibers as potential reinforcement in polymer composites. Journal of Reinforced Plastics and Composites, 35(7), 601-614. https://doi.org/10.1177/0731684415625822

Subagyo, A. Chafidz, A. (2018). Banana pseudo-stem fiber: preparation, characteristics, and applications. Intech, 32(1), 137-144. Retrieved from http://www.intechopen.com/books/trends-in-telecommunications-technologies/gps-total-electron-content-tec- prediction-at-ionosphere-layer-overthe-equatorial-region\%0AInTec

Sujatha, E. R., \& Selsia Devi, S. (2018). Reinforced soil blocks: Viable option for low cost building units. Construction and Building Materials, 189, 11241133. https://doi.org/10.1016/j.conbuildmat.2018.09.077

Vo, L. T. T., \& Navard, P. (2016). Treatments of plant biomass for cementitious building materials - A review. Construction and Building Materials. https://doi.org/10.1016/j.conbuildmat.2016.05.125

Yan, L., Chouw, N., Huang, L., \& Kasal, B. (2016). Effect of alkali treatment on microstructure and mechanical properties of coir fibres, coir fibre reinforcedpolymer composites and reinforced-cementitious composites. Construction and Building Materials, 112, $168-182$. https://doi.org/10.1016/j.conbuildmat.2016.02.182

Yan, L., Kasal, B., \& Huang, L. (2016). A review of recent research on the use of cellulosic fibres, their fibre fabric reinforced cementitious, geo-polymer and polymer composites in civil engineering. Composites Part B: Engineering, 92, 94-132. https://doi.org/10.1016/j.compositesb.2016.02.002

Yavuz Bayraktar, O., Kaplan, G., Gencel, O., Benli, A., \& Sutcu, M. (2021). Physico-mechanical, durability and thermal properties of basalt fiber reinforced foamed concrete containing waste marble powder and slag. Construction and Building Materials, $288,123128$. https://doi.org/10.1016/j.conbuildmat.2021.123128 